\title{
Translational Application of Circulating DNA in Oncology: Review of the Last Decades Achievements
}

\author{
Natalia O. Tuaeva ${ }^{1,+} \oplus^{(}$, Luca Falzone ${ }^{2,3, *,+}$ (), Yuri B. Porozov ${ }^{1,4}$, Alexander E. Nosyrev ${ }^{1}$, \\ Vladimir M. Trukhan ${ }^{1}$, Leda Kovatsi ${ }^{5}$, Demetrios A. Spandidos ${ }^{6}$, Nikolaos Drakoulis ${ }^{7}$ (D), \\ Alexandra Kalogeraki ${ }^{8}$, Charalampos Mamoulakis ${ }^{9}{ }^{\circledR}$, George Tzanakakis ${ }^{10}$, \\ Massimo Libra ${ }^{2,11, *(1)}$ and Aristides Tsatsakis 1,12 (i)
}

1 I.M. Sechenov First Moscow State Medical University (Sechenov University), 119048 Moscow, Russia; natalya.tuaeva@gmail.com (N.O.T.); yuri.porozov@gmail.com (Y.B.P.); rerik2050@mail.ru (A.E.N.); vladimir.trukhan@gmai.com (V.M.T.); tsatsaka@uoc.gr (A.T.)

2 Department of Biomedical and Biotechnlogical Sciences, University of Catania, 95123 Catania, Italy

3 Epidemiology Unit, IRCCS Istituto Nazionale Tumori “Fondazione G. Pascale”, 80131 Naples, Italy

4 ITMO University, Saint Petersburg 197101, Russia

5 Laboratory of Forensic Medicine and Toxicology, School of Medicine, Aristotle University of Thessaloniki, 54248 Thessaloniki, Greece; kovatsi@med.auth.gr

6 Laboratory of Clinical Virology, Medical School, University of Crete, Heraklion, 70013 Crete, Greece; spandidos@spandidos.gr

7 Research Group of Clinical Pharmacology and Pharmacogenomics, Faculty of Pharmacy, School of Health Sciences, National and Kapodistrian University of Athens, 15771 Zografou, Greece; drakoulis@pharm.uoa.gr

8 Department of Pathology-Cytopathology, Medical School, University of Crete, Heraklion, 70013 Crete, Greece; kalogerakimed@yahoo.gr

9 Department of Urology, University General Hospital of Heraklion, University of Crete, Medical School, Heraklion, 70013 Crete, Greece; mamoulak@uoc.gr

10 Laboratory of Anatomy-Histology-Embryology, Medical School, University of Crete, Heraklion, 70013 Crete, Greece; tzanakak@med.uoc.gr

11 Research Center for Prevention, Diagnosis and Treatment of Cancer, University of Catania, 95123 Catania, Italy

12 Department of Forensic Sciences and Toxicology, Faculty of Medicine, University of Crete, Heraklion, 71003 Crete, Greece

* $\quad$ Correspondence: luca.falzone@unict.it (L.F.); m.libra@unict.it (M.L.); Tel.: +39-095-478-1278 (L.F.); +39-095-478-1271 (M.L.)

+ The authors contribute equally to this work.

Received: 3 August 2019; Accepted: 12 October 2019; Published: 14 October 2019

\begin{abstract}
In recent years, the introduction of new molecular techniques in experimental and clinical settings has allowed researchers and clinicians to propose circulating-tumor DNA (ctDNA) analysis and liquid biopsy as novel promising strategies for the early diagnosis of cancer and for the definition of patients' prognosis. It was widely demonstrated that through the non-invasive analysis of ctDNA, it is possible to identify and characterize the mutational status of tumors while avoiding invasive diagnostic strategies. Although a number of studies on ctDNA in patients' samples significantly contributed to the improvement of oncology practice, some investigations generated conflicting data about the diagnostic and prognostic significance of ctDNA. Hence, to highlight the relevant achievements obtained so far in this field, a clearer description of the current methodologies used, as well as the obtained results, are strongly needed. On these bases, this review discusses the most relevant studies on ctDNA analysis in cancer, as well as the future directions and applications of liquid biopsy. In particular, special attention was paid to the early diagnosis of primary cancer, to the diagnosis of tumors with an unknown primary location, and finally to the prognosis of cancer patients. Furthermore, the current limitations of ctDNA-based approaches and possible strategies to overcome these limitations are presented.
\end{abstract}


Keywords: ctDNA; biomarker; oncology; liquid biopsy; NGS; mass-spectrometry; glioma; urological cancers; diagnosis; prognosis

\section{Introduction}

It has been widely demonstrated that several physiological and pathological conditions induce cells and tissues remodeling and, in turn, the rearrangement of stroma and tissue microenvironment. These events are generally sustained by necrotic or apoptotic processes, leading to the disaggregation of tissues and the consequent dissemination of cells and cellular debris in the intercellular space and in the bloodstream. Through these processes, circulating cells and DNA fragments reach the biological fluids and can be easily detected using different molecular techniques [1-3]. Other studies demonstrated that cells actively release cellular DNA in the extracellular space via the secretion of vesicles and exosomes, independently from cell necrosis or apoptosis [4,5]. This extracellular fraction of DNA is commonly called circulating free DNA (cfDNA), as the DNA fragments can be found in the biological fluids. The general term "cfDNA" encloses different types of circulating DNA, including cell-free DNA (cfDNA), cell-free fetal DNA (cffDNA), and circulating tumor DNA (ctDNA) [6].

Circulating tumor DNA is a tumor-derived fragmented DNA found in the bloodstream and other biological fluids, not associated with cfDNA which, on the contrary, is released by normal cells [7]. In the last decades, a growing body of evidence has defined the potential clinical value of ctDNA because it may recapitulate the entire tumor molecular profile. Therefore, it could be used for diagnostic, prognostic, monitoring, and therapeutic purposes [8].

Several mechanisms have been described to explain the mechanism of ctDNA release in the bloodstream or into other body fluids [2]. The most accredited hypotheses involve either the release of DNA from the necrotic cells of the primary tumor bulk or the loosening of DNA derived from the lysis of circulating tumor cells (CTC) in the bloodstream and lymphatic vessels [2]. In particular, several studies have hypothesized that ctDNA release is the combination of various biological processes, including apoptosis, necrosis, and tumor invasion $[1,9,10]$ (Figure 1). Furthermore, specific tumor features, i.e., the tumor localization, vascularization, and molecular characteristics, including loss of adhesion molecules (E-Cadherin, integrins, selectins, etc.), also facilitate the release of ctDNA and CTCs [11,12].

A

TUMOR INVASION

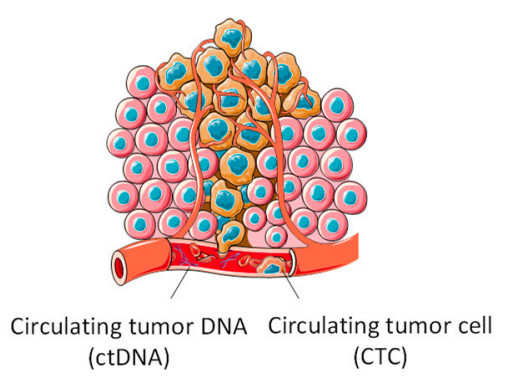

B NECROSIS

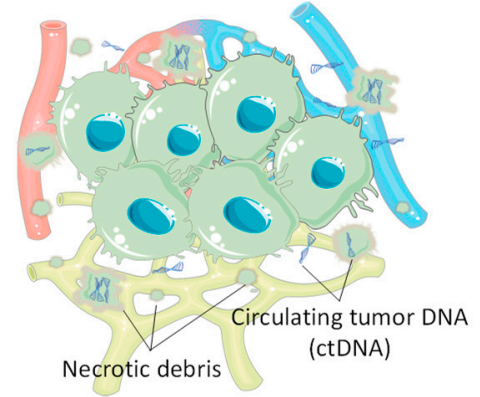

C
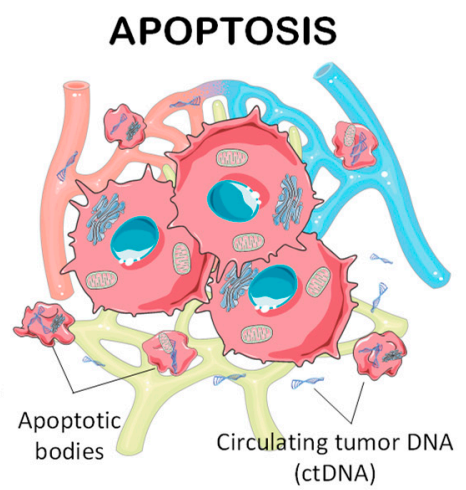

Figure 1. Release modalities of circulating tumor DNA (ctDNA) and circulating tumor cells (CTCs). (A) Invasive tumors release CTCs and ctDNA directly in the tumor infiltrating vessels or in invaded arteries and veins; (B) Necrotic cells release ctDNA directly into the cellular interstitium that reach the bloodstream through the lymphatic vessels; (C) Similarly, apoptotic cells release ctDNA directly in the cellular interstitium or through apoptotic bodies. 
Recent studies on circulating extracellular DNA in human biological fluids (blood plasma, serum, urine, etc.) were performed with the final goal of improving oncology practice. Circulating tumor DNA, as well as genomic and epigenetic alterations, such as single nucleotide polymorphisms (SNPs) [13], chromosome rearrangements, copy number variation (CNV) [14,15], microsatellite instability (MSI) [16], loss of heterozygosity (LOH) [17], microRNA alterations [18], and specific changes in DNA methylation patterns [19-21], have been widely explored. Potentially, circulating DNA is the carrier of the genetic information deriving from the primary cells or tissues [22-24]. For example, a circulating DNA methylation profile may mirror the tumor localization, as each tissue has a specific methylation pattern. Furthermore, the DNA methylation profile may also provide information about the nucleosome positioning of the DNA sequence [24]. In general, transcription factor footprints may reflect the epigenetic cellular landscape, and hence the tissue origin of a certain ctDNA. Thus, they may be used for the identification of the corresponding unknown primary cancer [22,23].

Recently, liquid biopsy, a new analytical approach based on the analysis of a peripheral blood sample for the identification of tumor-specific alterations directly in the bloodstream, was introduced in the clinical practice for diagnostic and prognostic purposes $[25,26]$. The goal of this approach was to replace tissue biopsy with minimally invasive techniques, simultaneously obtaining a large amount of DNA [27]. Indeed, it was widely proven that it is possible to recover cfDNA up to $100 \mathrm{ng} / \mathrm{mL}$ for healthy individuals and up to $1000 \mathrm{ng} / \mathrm{mL}$ for cancer patients from liquid biopsy samples [28]. Furthermore, the benefits of using the liquid biopsy are the high specificity and efficiency in monitoring tumor changes or disease progression. In this context, several studies demonstrated that liquid biopsy is able to spot precise circulating DNA mutations directly associated to a specific neoplasm [29,30]. This is possible because the short half-life of ctDNA (spanning between $16 \mathrm{~min}$ and $13 \mathrm{~h}$ ) allows immediate correlation with tumor cell status and thus offers the possibility of a continuous dynamic observation [31-34]. In contrast, the classic tissue biopsy provides only a single space-time snapshot and does not reflect on the dynamic heterogeneity of the tumor. Plasma/serum-derived ctDNA samples do not degrade until analysis, while tissue preparations are obligatory fixed, either in formalin or in paraffin, which creates a risk of DNA cross-linking and fragmentation, thus violating the DNA's structural integrity and interfering with its sequencing [35]. In detail, only $5 \times 10^{7}$ tumor cells are necessary to obtain detectable amounts of ctDNA, and $10^{9}$ cells are necessary to obtain an image using high-resolution computer tomography [9]. This represents only one of the advantages of liquid biopsy in contrast to tissue biopsy (Table 1) (Figure 2).

Table 1. Liquid biopsy versus tissue biopsy.

\begin{tabular}{lll}
\hline Characteristics and Scope & Liquid Biopsy & Tissue Biopsy \\
\hline Invasiveness & Minimally invasive & Invasive \\
\hline Study prescription time & On demand repeatedly & Prior a therapy prescription \\
\hline Sample degradation & No, long keeping in $-70^{\circ} \mathrm{C}[35]$ & Cross-linking and DNA fragmentation [35] \\
\hline $\begin{array}{l}\text { Tumor size/number of tumor cells for } \\
\text { detectable ctDNA }\end{array}$ & $5 \times 10^{7}$ cells [9] & $>10^{9}$ cells [9] \\
\hline Amount of biomaterial & $3 \mathrm{~mL}$ peripheral venous blood & Depending on the technique and organ \\
\hline Screening & Yes [36] & No \\
\hline Therapy choice & Yes & Yes \\
\hline $\begin{array}{l}\text { Continuous dynamic } \\
\text { observation (monitoring) }\end{array}$ & Yes, half-life of ctDNA between 16 min and & No, too traumatic \\
\hline Response to therapy & $13 \mathrm{~h}[32-34]$ & No \\
\hline Residual tumors & Yes $[21,34]$ & No \\
\hline Relapse prognosis & Yes $[21,34]$ & No \\
\hline
\end{tabular}




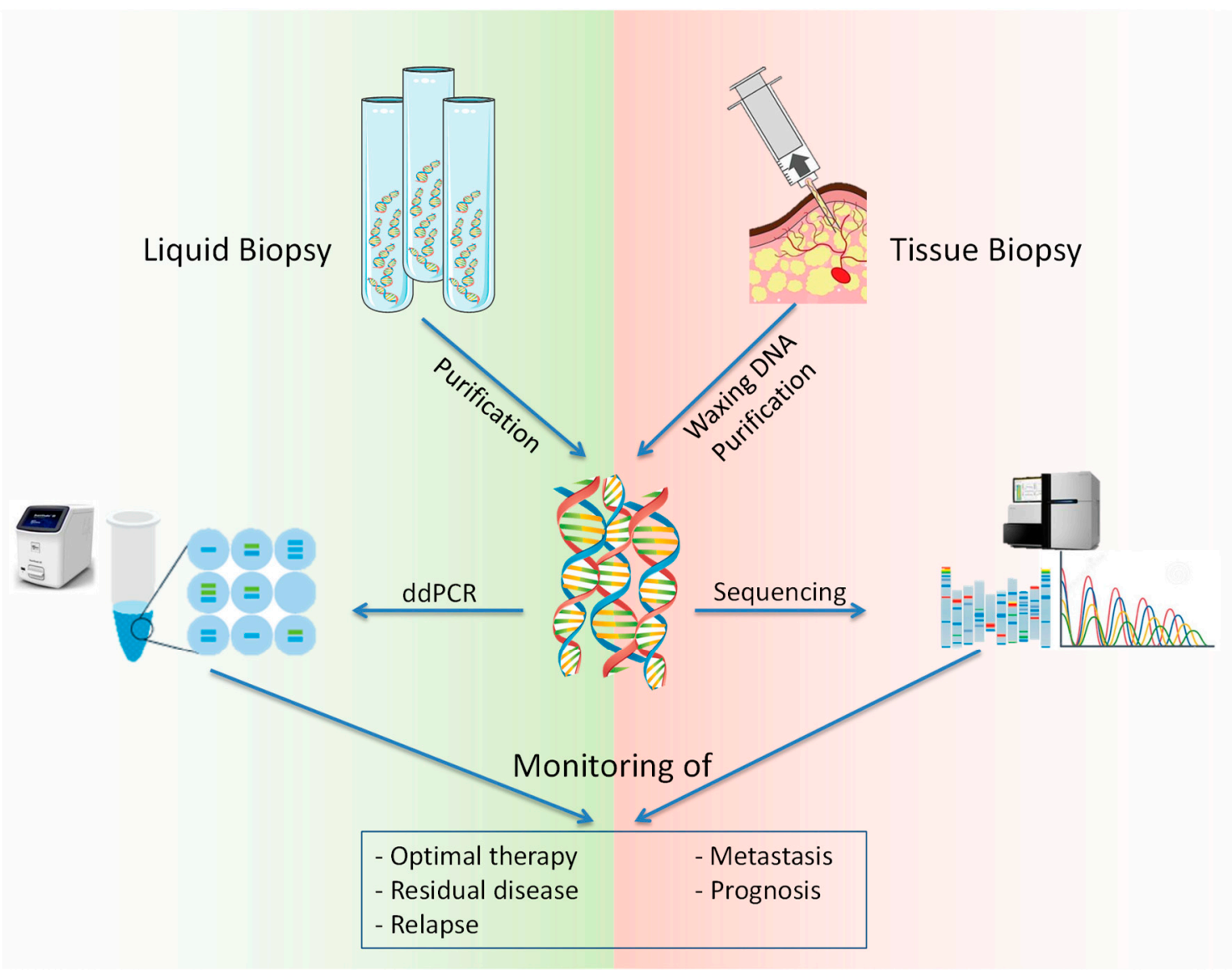

Figure 2. Comparison between liquid biopsy and tissue biopsy. The purification and/or extraction of DNA from liquid or tissue biopsy allows the researcher to perform high-throughput molecular analysis (Next Generation Sequencing or droplet digital PCR) in order to obtain significant data to define the prognosis of patients, to monitor the therapeutic efficacy and to predict the development of metastasis and relapse. Therefore, similarly to tissue biopsy, liquid biopsy allows the clinicians to obtain informative clinical data with a less invasive and less expensive method.

Consequently, ctDNA levels in plasma or serum may offer early diagnosis in the very few months of disease progression, even before any detectable change in the tumor images obtained through X-Ray, MRI, PET, CT, or PET/CT or changes in blood protein markers levels [37,38]. In this context, several studies demonstrated that the analysis of ctDNA levels during anticancer treatments can be used in combination with the above mentioned imaging techniques in order to perform a more comprehensive evaluation of the tumor progression, thus optimizing the monitoring procedures of tumor [39-41]. The introduction of ctDNA analysis in clinical practice could indicate when to perform imaging diagnostic procedures to physicians, reducing the patients' exposure to radiation and predicting inefficient treatments $[42,43]$. Nevertheless, still today ctDNA analysis cannot completely replace the above-mentioned imaging techniques.

It is clear that ctDNA levels correlate well with tumor size (tumor load) [38] and sharply decrease after resection [37]. Thus, liquid biopsy is a promising tool for detecting residual tumors, metastases, tumor progression or regression during therapy, or disease prognosis [21,34]. However, besides these advantages, the liquid biopsy may present some limitations, mainly related to the specific and highly sensitive instruments necessary to determine the expression levels of small quantities of ctDNA circulating in the peripheral blood [44].

This review discusses the most advanced applications of ctDNA analysis which have been developed in the last decade, listed in Table 2 (Table 2). 
Table 2. Tumor circulating DNA blood tests in personalized cancer diagnostics and cancer characterization.

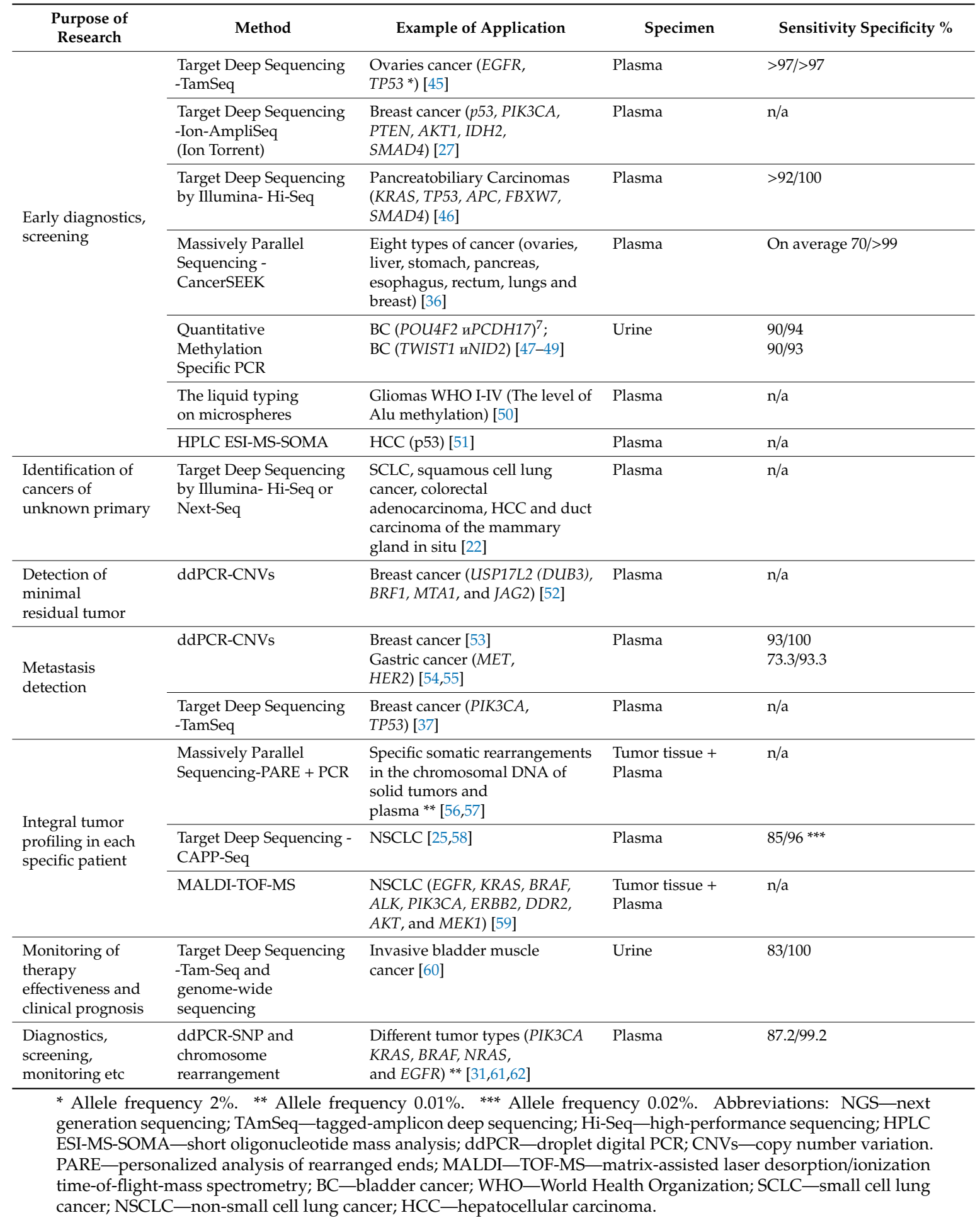

\section{NGS, ddPCR, and Liquid Biopsy for ctDNA Analysis}

It is well-accepted the notion that early diagnosis of tumor is a key factor in the management of cancer patients, which is essential to enhance the overall survival and progression-free survival of patients [63]. The main objective of early diagnosis is to detect symptomatic patients as early as possible in order to avoid delays in the administration of anticancer treatments. 
The concept of "early diagnosis" should not be confused with "screening," the former consisting in the identification of a disease in healthy and asymptomatic patients through the use of tests and/or medical procedures applied to specific population at risk for such disease [64].

Compared to early diagnosis, cancer screening consists of a specific investigative strategy encompassing a wider geographical area and is directed toward a target population. In this context, several screening programs have been developed for the early identification of different types of cancers [65]. Both early diagnosis and screening programs were effective in reducing cancer deaths [66].

In the last decade, greatest attention has been paid to the use of liquid biopsy as a good screening method for both hematological and solid tumors, as well as its role as a new diagnostic test available for the early diagnosis of cancer [67].

In this context, the development of novel next generation sequencing (NGS) methods has made a significant contribution to the early diagnosis of cancer based on the detection of low-frequency mutations in ctDNA [68]. As known, NGS is a high-throughput technology able to sequence the whole genome at once. In recent years, different types of NGS approaches have been developed. All these techniques are generally characterized by the fragmentation of the genomic DNA into small sequences, which are subsequently amplified in order to perform the automated sequencing of multiple fragments at once (the so-called massively parallel sequencing) [69]. Nowadays, NGS is applied to several analyses, including ctDNA sequencing.

NGS allows the detection of ctDNA changes occurring in the whole genome [70-72], thus providing an opportunity to comprehensively profile tumor-related genetic changes $[73,74]$. This is important to have the possibility to detect cancer clones able to mutate rapidly and, therefore, to become resistant to specific anticancer drugs [74]. Target diagnostic panels of tumor-specific mutations ("hot spots") in ctDNA, including the most characteristic mutations of proto-oncogenes and suppressors, are being developed for primary preclinical diagnosis based on NGS [45]. Several types of such platforms are currently in use, including tagged-amplicon deep sequencing (TAmSeq) [31,45,75], Ion-AmpliSeq (Thermo Fisher Scientific) [76-78], and molecular cluster sequencing of Illumina [46]. Indeed, Forshew et al. identified mutations in the onco-suppressor gene TP53 of ctDNA in plasma samples of 46 patients with progressive ovarian cancer with a sensitivity and specificity greater than $97 \%$, whereas the frequency of the mutant allele occurrence in the circulating DNA in plasma samples was no more than $2 \%$ using TAm-Seq [45]. In a separate study, the authors identified a particular mutation of the EGFR gene, not detected in the primary ovarian biopsy, in plasma circulating DNA. Using the same technology, these authors monitored the tumor dynamics through the estimation of 10 concomitant mutations in patients with metastatic breast cancer [45]. Moreover, Hi-Seq (Illumina) sequencing of the five "hot points" (KRAS, TP53, APC, FBXW7, SMAD4) in ctDNA from 26 patients with pancreatobiliary carcinoma was carried out with a diagnostic accuracy of $97.7 \%$, sensitivity of $92.3 \%$, and specificity of $100 \%$ [46].

Recently, an exceptionally promising method (CancerSEEK) was developed for the primary screening of eight types of cancer (ovaries, liver, stomach, pancreas, esophagus, rectum, lungs, and breast), which focuses on a small panel of markers (16 genes and eight proteins) and is based on massively parallel sequencing [36]. The authors emphasized that the method is intended for screening, and therefore differs from other molecular tests based on the analysis of a large number of genes with the aim of identifying therapeutic targets. The small panel may reduce false positive results and the elevated costs of a larger analysis [36,79]. The screening was performed on 1005 patients with metastatic tumors and 812 healthy individuals, showing only $1 \%$ of false positive results, $70 \%$ median sensitivity, and $\geq 99 \%$ specificity [36].

The GRAIL study, launched by Illumina to develop its preclinical cancer detection technology in blood by high-intensity sequencing assays, population-scale clinical studies, and machine learning such as neural networks, started in 2016 and will last five years. The GRAIL Clinical Research Program set up is presented in Supplementary Table S1. Thus, we can expect to have results soon, which will allow the development of a method for early cancer diagnosis in 2020-2021 (Table S1). 
Next-generation sequencing (NGS) platforms are not the only tools available for the efficient analysis of ctDNA samples. In the last years, the digital PCR, a new type of polymerase chain reaction, was developed and efficiently used for the detection of small amount of ctDNA [80]. Among the different types of digital PCRs, the most promising is the droplet digital PCR (ddPCR) technique, which ensures high levels of sensitivity, as well as specificity (1:10,000 copies of DNA). Several studies demonstrated that ddPCR allows the identification of mutated DNA in peripheral blood and other liquid matrices with a high grade of accuracy, thus representing one of the most effective methods to analyze liquid biopsy samples for diagnostic purposes [81,82].

McEvoy and coworkers (2018) analyzed the circulating-free DNA samples of 32 melanoma patients and showed that ddPCR was able to detect BRAF, NRAS, or KIT mutations in all the patients with a mutational tumor burden $>10$ (23 out of 32) [83]. Similarly, a recent meta-analysis of 11 non-small cell lung carcinoma (NSCLC) studies showed that ddPCR displays a good performance for the detection of EGFR T790M mutation in ctDNA samples from a total of 872 advanced NSCLC patients. In particular, the overall concordance between plasma and tissue estimation was $81.2 \%$, while the pooled analysis revealed that ddPCR test performs with $86.9 \%$ (95\% CI, 80.6\%-91.7\%) of specificity and $70.1 \%(95 \% \mathrm{CI}$, $62.7 \%-76.7 \%$ ) of sensitivity in detecting the T790M EGFR mutation in ctDNA samples from NSCLC patients [84]. Other similar studies were performed involving oral cancer patients [85], breast cancer patients [86], chronic myelogenous leukemia patients [87], and others.

Overall, both the NGS and the dAPCR methodology may be used for the effective detection of ctDNA. The choice of the best platform depends on the molecular target examined. The NGS is used to carry out a wide screening of the possible circulating mutations associated with the tumor, whereas the ddPCR is generally used for the identification of specific tumor mutations.

\section{Epigenetic Modifications of Circulating DNA May Reflect Tissue Origin of an Unknown Primary Cancer}

It was widely demonstrated that a wide range of substances, including pesticides, pollutants, fibers, and heavy metals, might induce genetic and epigenetic damages to the cells predisposing for a plethora of diseases, including cancer [88-92]. Other physio-pathological processes, such as infections, chronic inflammation, and microbiota dysbiosis, have been also associated to the development of cancer [93-96].

In this context, the recent theory of real life risk simulation (RLRS) demonstrated that all the aforementioned risk factors interact with each other, highlighting a real hazard for human health [97-99]. According to this theory, demonstrated both in animal and human models [100-102], cumulative and synergistic effects of various seemingly harmless substances can be highlighted or even unveiled as leading mechanisms of epigenetic alterations and, in turn, the development of neurological disorders, cancers, and other diseases [103].

It is clear that all these environmental factors are able to induce the development of cancers through several molecular modifications directly detectable in ctDNA samples. A growing body of evidence reported that the epigenetic changes induced by all these mechanisms might predict the presence of diseases, as well as the aboriginal tissue. In this way, it is possible to determine the precancerous or cancerous tissue of origin, thus identifying cancers with unknown primary localization whose frequency is $4-5 \%$ of all registered invasive cancer types [104].

Circulating DNA may contain genetic features of cells derived from tissue from other individuals, thus its analysis is widely used as a non-invasive prenatal diagnosis and for predicting the risk of host versus graft disease in transplant medicine [105]. In both cases, DNA differences between two different organisms provide significant assistance in their identification. The epigenetic differences allow the identification of the tissue where the circulating DNA is derived from. In fact, it has previously been demonstrated that the distance between nucleosomes varies among cell types depending on the state of chromatin and gene expression [106-108]. Snyder (2016) demonstrated that deep sequencing of circulating DNA in plasma allows the generation of nucleosome location maps. The obtained 
maps correlated well with the architecture of the nucleus, genes structure, as well as their cellular expression [22]. Furthermore, it was demonstrated that small fragments of circulating DNA contain traces of nuclear transcription factors. Indeed, DNAse I fragmentation, used to study the tissue origin of circulating DNA, showed that hematopoietic cells have a large proportion of fragments with an extended distance between the nucleosomes due to the transcription factors mediated DNAse I-sensitive (DNS) sites shielding. The transcription start site (TSS) protection patterns are also quite different among various cell types. The epigenetic characteristics of circulating DNA in healthy humans indicate that it originates mainly from lymphoid and myeloid cells due to their physiological short lifespan. Furthermore, five patients suffering from various stage IV cancers (small cell lung cancer, squamous cell lung cancer, colorectal adenocarcinoma (CRC), hepatocellular carcinoma, and ductal carcinoma of the mammary gland in situ) showed ctDNA-derived nucleosome spacing patterns overlapping with relevant reference maps from corresponding cancer cell lines. For example, ctDNA from a patient with hepatocellular carcinoma showed the highest correlation with the HepG2 cell line (cell line for hepatocellular carcinoma), and the tumor ctDNA of breast duct carcinoma corresponded to MCF-7 (metastatic adenocarcinoma cell line). The limitation of this study was the small number of samples studied $(n=8)$ and the relatively small size of the reference data set of cell lines and tissues used for comparison $(n=76)$ [22]. For a full assessment of the potential and limitations of this approach, it is necessary to increase the number of samples studied, as well as the range of physiological states and diseases related to these samples.

Besides nucleosome modification, other epigenetic alterations are widely described in literature and might be responsible for cancer development and progression [109]. All these epigenetic changes can be detected through the analysis of ctDNA or other circulating elements (miRNAs, IncRNA, exosomes, etc.). As described above, environmental factors may induce molecular alterations in the DNA structure or may lead to the expression of non-coding RNAs (ncRNAs) which are, in turn, able to modulate the expression of several genes involved in cancer development $[110,111]$. In the first case, the most studied and common DNA backbone modification is the methylation occurring in the cytosine of CG dinucleotides (CpG site), able to modulate gene expression [112]. With respect to the modulation of non-coding RNAs or other elements, such as exosomes, different studies demonstrated that epigenetic changes may induce their strong deregulation, thus favoring the development and progression of cancer $[18,113,114]$.

Both these epigenetic modulations, i.e., DNA methylation and alterations of the expression levels of ncRNA, can be effectively studied through liquid biopsy and the analysis of circulating nucleic acids $[115,116]$.

Liang W. and colleagues developed recently a blood-based test for the detection of early-stage lung cancer using a non-invasive and high-sensitive high-throughput DNA bisulfite sequencing test. In particular, through the sequencing of more than 250 tissue samples, the authors identified nine methylation markers, achieving 79.5\% (63.5\%-90.7\%) of sensitivity and $85.2 \%(66.3 \%-95.8 \%)$ of specificity when these markers were tested in a validation cohort of circulating DNA obtained from lung cancer and healthy patients [115].

Similarly, Menschikowski $M$ and coworkers developed an optimized bias-based pre-amplification-digital droplet PCR (OBBPA-ddPCR) for the detection of methylated tumor DNA fragments levels with the goal of developing a diagnostic tool for early prostate cancer diagnosis. In particular, the authors showed that as few as five copies of methylated ctDNA out of 700,000 copies of unmethylated ctDNA fragments were identified through the use of ddPCR pre-amplification. Using this technique for the analysis of serum samples derived from 22 prostate cancer patients and 18 normal individuals, the authors reported a specificity of $100 \%$ in the detection of specific methylated markers [117].

Considering the analysis of ncRNA as indicator of epigenetics modification in cancer, several studies demonstrated the utility of liquid biopsy for the analysis of miRNAs and lncRNAs expression levels. In a recent review article, Pardini B. reported the state of the art of miRNAs analysis in several 
cancer types by using liquid biopsy. The authors showed that specific sets of miRNAs were successfully identified for almost all solid and hematological cancers [118]. In the same manner, the authors described the important achievements regarding the analysis of other circulating biomarkers in liquid biopsy samples, including piRNAs, snRNAs and snoRNAs, circRNA and lncRNA [118].

\section{Circulating DNA as a Prognostic Criterion in Oncology}

The prognostic properties of circulating DNA in oncology could help in choosing the most appropriate therapeutic approach (for example, in the case of drug resistance), thus avoiding ineffective treatment methods, as well as unwanted side effects and associated costs [119]. Nevertheless, ctDNA analysis for the prognosis of disease progression remains controversial. For example, Huang Z.H. et al. analyzed the correlation between plasma levels of and clinical-pathological parameters in breast cancer patients. Although circulating DNA concentrations were higher in patients with advanced cancer than in controls, there was no statistically significant difference [120]. In contrast, in patients with kidney carcinoma treated with sorafenib, higher ctDNA levels correlated with poorer prognosis [121], or predicted postoperative relapse with high sensitivity $(91 \%)$ and specificity $(100 \%)$ [122]. The absence of significant correlation of the total circulating DNA pool with prognosis may reflect the presence of other DNA sources, which may be associated with tumor growth (for example, apoptosis or necrosis of the adjacent tissue cells).

A 2015 study focusing on predictive value comparison of ctDNA pool levels and circulating tumor cells revealed that the ctDNA concentrations neither reflected disease prognosis nor survival, although the number of circulating cells slightly correlated with both overall survival (OS) and progression-free survival (PFS) time [123]. The interference of separate factors, such as the individual activity of blood nucleases or enhanced phagocytosis, which, in some cases, leads to paradoxically low levels of ctDNA in patients with progressive disease, is also possible. Indeed, this was observed in several metastatic breast cancer patients [124] and two patients with bladder carcinoma [125]. The quantitative indicator is unlikely to be informative for predicting the patients' outcome and it is necessary for future efforts to focus on specific DNA mutations and polymorphisms.

These data show that the analysis of ctDNA for prognostic purposes may be valid only for some tumors. In this context, concordant data were generated for some cancers, such as cutaneous melanoma, NSCLC, and colorectal cancer, where the evaluation of ctDNA before the beginning or during pharmacological treatments provided useful information to define patients' OS and PFS [126-129]. Moreover, encouraging evidence shows that the evaluation of ctDNA or circulating tumor cells is useful to predict the response rate of patients to anti-tumor treatments, including recent immunotherapy. In this regard, in NSCLC and melanoma patients with advanced tumors, it was demonstrated that the evaluation of different molecular factors contained in liquid biopsy samples gave accurate information for the prediction of treatment outcomes [130]. The NGS evaluation of tumor mutational burden in NSCLC plasma samples revealed that patients with more than six ctDNA genetic alterations had higher response rates when treated with immune checkpoint inhibitors [131] and that more than 10 genetic alterations were associated with a prolonged PFS [132].

Other studies demonstrated that the initial increase of ctDNA percentages, followed by a drastic reduction of the number of mutated DNA copies, is associated to a good clinical response and therefore to a better prognosis. On the contrary, the initial reduction of mutated DNA, followed by a new increase of ctDNA, is associated to therapeutic failure and the onset of drug resistance mechanisms $[130,133]$.

Thus, in addition to several ongoing studies, these data demonstrate that the analysis of ctDNA and liquid biopsy samples obtained during the treatment may give important information capable of monitoring the prognosis of patients, as well as identifying specific therapeutic protocols pursuing the principles of personalized medicine.

It is important to note that differences in both ctDNA amount and CTCs number could be linked to the pathological stage of tumor. In particular, a recent study performed on early and metastatic breast cancer patients showed significant differences both in CTCs and ctDNA detectable levels in early versus 
metastatic tumors for PIK3CA, E545K, and H1047R hotspot mutations [134]. Additionally, Tzanikou E. and colleagues demonstrated that such mutations were present in $39 \%$ of early cancer ctDNA plasma samples and in $47.9 \%$ of metastatic cancer ctDNA plasma samples. Similarly, the analysis of CTCs showed that the $48.2 \%$ of early cancer patients and the $66.6 \%$ of metastatic breast cancer patients presented the analyzed PIK3CA mutations, not detected in the healthy controls [134]. Taken together, these data showed that the analysis of CTCs was more sensitive compared to ctDNA analysis for the identification of PIK3CA mutations in liquid biopsy samples obtained from breast cancer patients.

Other studies demonstrated that the concomitant evaluation of CTCs and cfDNA can be used for an effective cancer prognosis. Marie-Hélène Delfau-Larue and colleagues reported that CTCs and bcl2-JH mutation detected in cfDNA might predict the disease progression, reflecting the tumor burden [135]. In particular, the researchers demonstrated that the analysis of both CTCs and cfDNA in follicular lymphoma patients at early-, mid-, and late-stages might give important information for a correct prognosis. Importantly, both CTCs and cfDNA correlate with total metabolic tumor volume (TMTV). However, only the number of bcl2-JH mutated copies detected in cfDNA adds extra prognostic information to the TMTV evaluation [135].

Although ctDNA analysis has been shown to be useful for both early diagnosis of tumors and to define cancer patients' prognosis, the analysis of CTCs appears to be more suitable for monitoring patients with medium or advanced stage of the tumor in order to establish the overall survival and the progression free survival. Starting from these considerations, the research group coordinated by Rossi G. recently performed a study on metastatic breast cancer patients evaluating both CTCs and ctDNA [136]. In this study, the authors confirmed that CTCs levels at baseline are predictors of both PFS and OS in metastatic breast cancer setting, with a cutoff level of five cells per $7.5 \mathrm{~mL}$ of the whole blood. The authors further demonstrated that ctDNA correlated with the prognosis of patients and the tumor burden with a concordant rate (ranging between $72.5 \%$ and $100 \%$ ) in the identification of mutations observed in tissue biopsies [136].

Overall, these studies showed that the presence of ctDNA or CTCs is associated with the presence of tumors, even early-stage tumors, while higher amounts of ctDNA and/or CTCs are correlated with higher risk of disease progression and with a poorer prognosis for the patients, independently from their tumor stage.

\section{Circulating Tumor DNA Analysis for Cancer Personalized Medicine}

A personalized approach in cancer diagnosis implies integral tumor profiling for each individual patient, which might be possible by tracking plasma ctDNA tumor-related mutations. The purpose of studying biopsy specimens maybe the selection of a personalized anticancer therapy, relevant to the mutational profile of the specific tumor. Application of the plasma ctDNA analysis allows for the monitoring of disease dynamics and the prescribed therapy effectiveness in order to detect any residual tumor after resection, relapse, or even metastasis within a particular patient.

Progress in this area would be impossible without the development of appropriate screening techniques. Since the frequency of mutant tumor alleles is often less than $0.01 \%$ of the total pool of circulating DNA [33,137], the detection methods have to be sufficiently sensitive. In 1999, the droplet digital PCR technology [138] was successfully introduced into practice [139-142]. The breakdown of the reaction mixture into 20,000 individual droplet microreactors with one target DNA molecule as a matrix allows direct counting of the reaction product when the ratio of the minor allele to the total circulating DNA pool is $1: 10,000(0.01 \%)[140,143,144]$. For that reason, the ddPCR technique is referred as the "golden standard" for quantifying rare mutations $[144,145]$. Another approach is the establishment of copy number variations (CNVs), a biomarker used for detecting minimal residual breast cancer [52], metastatic breast cancer [53], stomach cancer [54,55], and others [62,143]. Experience gained during the utilization of the ddPCR method has been published in a book by Karlin-Neumann (2018) in the form of detailed protocols [145]. 
In 2010, the Velculescu's group developed personalized analysis of rearranged ends (PARE) as a method of identifying specific somatic rearrangements in the chromosomal DNA of solid tumors. This method is based on massively parallel sequencing, followed by PCR analysis in order to detect the specific biomarkers in the bloodstream [56,57]. In the study of McBride, the validity of this approach was confirmed through the analysis of more than 100 samples of solid tumors, including cancers of the breast, pancreas, ovaries, bones, and lungs [146]. In all cases, with the exception of one sample, the sites of rearrangements were successfully identified and about $85 \%$ of the samples presented more than 10 rearrangements simultaneously.

Newman and coauthors developed the technology "cancer personalized profiling by deep sequencing" (CAPP-Seq) through the utilization of biotinylated oligonucleotides specific to the most recurrent mutating regions in order to monitor ctDNA in patients with NSCLC [58]. Using this approach, ctDNA was identified in $100 \%$ of patients with stage II-IV NSCLC and in $50 \%$ of patients with stage I disease with a specificity of $96 \%$ and with a frequency of mutant allele fractions of about $0.02 \%[25,58]$.

A personalized approach based on the genotyping of tumor tissue and the subsequent search of ctDNA in the bloodstream was successfully tested in small pilot studies in bladder urothelial carcinoma [125,147,148]. Later, in the study of Christensen E. (2017), three different NGS-based approaches were used and deletions, insertions, inversions, and intra- and inter-chromosomal translocations were investigated in 337 samples of 12 patients over 20 years [148]. Patel et al. reported that the mutant ctDNA detection in urine by Tam-Seq and genome-wide sequencing could be successfully used for monitoring neoadjuvant therapy effectiveness and clinical prognosis in patients with invasive bladder muscle cancer [60].

A valid support for the identification of new ctDNA biomarkers for the personalized research in cancer may be provided by the analysis of the molecular data already available for several cancers and collected in big consortia like The Cancer Genome Atlas, COSMIC, or GEO Datasets [148-152]. In particular, with the advent of bioinformatics and omics sciences, it is possible to select in silico the putative molecular targets to be analyzed in ctDNA samples, including genetic and epigenetic biomarkers [153-156]. Alternatively, it might be useful to perform a massively parallel sequencing as done by Leary and coworkers in order to select specific targets to be analyzed in ctDNA [57].

In this context, different experimental and computational studies allowed the identification of a specific set of genetic and epigenetics alterations potentially detectable in liquid biopsy samples [157,158]. The investigation of the presence of BRAF, PTEN, and KIT mutations in ctDNA from liquid biopsy samples obtained from melanoma patients was previously described. The analysis of the specific mutations is certainly not accidental. Indeed, these mutations are also analyzed in liquid biopsy samples as they are the most frequently detected mutation in melanoma tumor biopsies, as demonstrated by several studies $[159,160]$. Other studies have shown that in melanoma patients, the utilization of liquid biopsy samples analysis of other tumor associated factors, including MMP-9 or specific pro-tumoral miRNAs, may represent a useful diagnostic and prognostic approach for the management of this pathology $[114,126]$. Similarly, different studies showed the usefulness of analyzing the EGFR and KRAS mutations in ctDNA samples obtained from NSCLC patients [84,161].

Colorectal cancer (CRC) patients are often diagnosed when the disease is already advanced or metastatic due to the late onset of tumor symptoms and poor patient compliance to the current diagnostic methods [162]. Hence, a non-invasive, easily accessible diagnostic tool which can detect CRC at an early stage (adenoma) might represent a step forward [163]. For this purpose, numerous studies have studied the potential application of ctDNA detection as a new diagnostic tool. Thankfully, benign tumors and non-neoplastic lesions do not release ctDNA in the circulation making easier the design of a diagnostic ctDNA panel for CRC diagnosis [164]. Until now, only few mutated genes in circulating DNA were confirmed to be valuable as diagnostic tools. For example, the hyper-methylated SEPT9 gene and the combination of SEPT9/ALX4 mutated genes. Interestingly, the analysis of gene panels compared with single gene mutation tests are best in terms of sensitivity and specificity. For instance, 
SEPT9/ALX4 panel exhibited a level of $71 \%$ sensitivity and $95 \%$ specificity for advanced adenomas, thus supporting SEPT9/ALX4 as a biomarker for precancerous lesions [165]. Nonetheless, attempts to achieve an even higher sensitivity and specificity have led to the proposal of a wider gene panel that could include genes such as HJC1, CYCD2, PAX5, RB1, SRBC, NPY, PENK, WIF1, ALX4, HLFT, HPP1, MLH1, APC, CDKN2A/P16h, TMEFF2, NGFR, FRP2, NEUROG1, and RUNX3 [164,166]. Moreover, another panel consisting of methylated ALU83, ALU244, OSMR, and SFRP1 has also demonstrated its diagnostic value [167]. It is noteworthy that circulating DNA panels have also proved to be useful for prognostic (APC, KRAS, TP53, and PI3KCA, methylated WIF1 and NPY), predictive (APC, KRAS, TP53), and therapy tailoring (KRAS, BRAF, MET, ERBB2, FLT3, EGFR, and MAP2K1) [168,169]. Accordingly, other independent studies demonstrated that KRAS mutation detected in liquid biopsy samples can be proposed as a valid biomarker of diagnosis and prognosis of CRC $[170,171]$. Other studies confirm the potential diagnostic and prognostic significance of $A P C, m S E P T 9$, and BRAF alterations [172,173].

Regarding breast cancer, no conclusive studies have been generated so far. Several studies have tried to propose the evaluation of HER2, PIK3CA and PD-L1 expression in ctDNA or circulating tumor cells. However, the specificity and sensitivity values of the analyses were not convincing and the discordance of the data obtained among the molecular subtypes of mammary tumors and among the tumor stages limited the statistical significance of these circulating biomarkers evaluation [174-176].

In the following chapters, the analysis of ctDNA diagnostic and prognostic potential will be discussed for the glioma and urothelial cancers.

Therefore, it is evident that there is no single circulating biomarker for the diagnosis and prognosis of all tumors, but different markers specific for different tumors might exist (Table 3). On this basis, the evaluation of a panel of circulating alterations may provide important information to the clinicians for a correct patient diagnosis and prognosis. 
Table 3. Overview of the most relevant ctDNA and CTCs analyses in different cancer types.

\begin{tabular}{|c|c|c|c|}
\hline Molecular Target & Sample Type & Technology & Study(ies) \\
\hline \multicolumn{4}{|c|}{ Non-Small Cell Lung Carcinoma } \\
\hline \multirow{3}{*}{ EGFR mutation } & ctDNA & ddPCR & [177] \\
\hline & ctDNA & ddPCR & [178] \\
\hline & CTCs & NGS & [179] \\
\hline \multirow{3}{*}{$P D-L 1$ expression } & CTCs & Immunofluorescence & [180] \\
\hline & ctRNA & qPCR & [175] \\
\hline & CTCs & Immunofluorescence & [181] \\
\hline \multicolumn{4}{|l|}{ Colorectal Cancer } \\
\hline \multirow{3}{*}{$A P C$ mutation } & ctDNA & NGS & [172] \\
\hline & CTCs & NGS & [182] \\
\hline & ctDNA & ddPCR & [183] \\
\hline \multirow{4}{*}{ KRAS mutation } & ctDNA & COLD PCR, Microarray, ddPCR & [184] \\
\hline & ctDNA & NGS & [185] \\
\hline & ctDNA & ddPCR & [139] \\
\hline & CTCs & Nested PCR & [186] \\
\hline \multirow{3}{*}{$B R A F$ mutation } & $\operatorname{ctDNA}$ & PCR-Microarray & [187] \\
\hline & ctDNA & ddPCR & [188] \\
\hline & CTCs & qPCR & [189] \\
\hline mSEPT9 methylation & ctDNA & Real-Time PCR & [190] \\
\hline \multicolumn{4}{|l|}{ Breast Cancer } \\
\hline \multirow{2}{*}{ HER2 expression } & ctDNA & NGS & [191] \\
\hline & CTCs & Immunofluorescence & [192] \\
\hline \multirow[b]{2}{*}{$P D-L 1$ expression } & ctRNA & qPCR & [175] \\
\hline & CTCs & $\begin{array}{c}\text { Western blot } \\
\text { Flow Cytometry } \\
\text { Immunocytochemistry }\end{array}$ & [193] \\
\hline \multirow{4}{*}{ PIK3CA mutation } & ctDNA & ddPCR & [176] \\
\hline & ctDNA & NGS & [194] \\
\hline & ctDNA & NGS & [195] \\
\hline & CTCs & ddPCR & [134] \\
\hline \multicolumn{4}{|l|}{ Cutaneous Melanoma } \\
\hline \multirow{3}{*}{$B R A F$ mutation } & ctDNA & ddPCR & [126] \\
\hline & CTCs & ddPCR & [196] \\
\hline & ctDNA & Exome NGS & [197] \\
\hline \multirow{2}{*}{ PTEN mutation } & ctDNA & SNPase-ARMS qPCR & [198] \\
\hline & CTCs & NGS RNA & [199] \\
\hline TERT promoter mutation & ctDNA & ddPCR & [200] \\
\hline \multirow{2}{*}{ KIT mutation } & ctDNA & NGS & [201] \\
\hline & CTCs & hemi-nested PCR & [202] \\
\hline
\end{tabular}




\section{Circulating DNA in Glioma Diagnosis}

Brain tumors are quite difficult to diagnose and are the least treatable. Taking into account the fatal nature of gliomas, the importance of early diagnosis for the patient is of paramount importance [203]. Imaging techniques do not provide comprehensive diagnostic information and biopsy is difficult to obtain. In this case, the use of liquid biopsy is important [204]. The amount of tumor DNA entering the bloodstream in brain tumors is the smallest compared with other tumors, presumably due to the low permeability of the blood brain barrier (BBB) [32]. Importantly, the Alu repeat is one of the most common mobile genetic elements belonging to the short interspersed nuclear element superfamily. It accounts for $10 \%$ of the entire genome and is therefore available for research, even with small amounts of ctDNA, as in case of brain pathologies. Alu elements contribute to the development of the disease by two mechanisms: Through insertional mutagenesis and non-allelic homologous recombination, inducing genetic deletions and duplications [205]. Normally, $67.5 \%$ of Alu sequences are methylated [50], which hinders their movements in the genome, limiting the level of genetic instability in a healthy cell. A decrease in the methylation level of MGEs increases their motility, causing the genetic instability commonly observed in tumor cells [205-207]. Chen et al. (2016) investigated the methylation of plasma Alu repeats in 109 patients with gliomas of four stages of malignancy according to WHO (WHO I-IV) and in 56 patients with benign brain tumors (meningioma and pituitary gland tumor). They used liquid typing on microspheres capable of interacting with 5-hydroxymethylcytosine $(\mathrm{hmC})$ or thymidine in CpG islands (CGIs) of Alu elements following bisulfite conversion. The level of Alu methylation in patients with gliomas was $55.62 \%$. In patients with benign brain tumors, it was $69.16 \%$, and in healthy individuals, it was $67.54 \%$. Differences between patients and controls were statistically significant, and no statistical significance was reported among different types of malignant gliomas. When grouping patients based on mutations in the IDH and TERT genes, the presence of wild-type IDH and mutant TERT in ctDNA (which causes the most unfavorable prognosis) was positively correlated with the lowest Alu methylation levels. The limitation of this work was the prevalence of hypo-Alu-methylation compared with other tumors and physiological conditions, which requires a more focused approach [206]. Nevertheless, the method revealed a significant correlation between the level of Alu methylation and the life expectancy of patients with gliomas, which is vital for prognostic purposes. In addition, regarding tumor stage, Chen et al. showed that liquid biopsy can effectively detect the methylation status of Alu sequences in all cancer stages. In particular, the authors identified lower methylation levels of Alu in grade III-IV advanced gliomas compared to low-grade gliomas (grade I-II) [206]

Faria et al. (2018) [119] determined the changes in circulating DNA concentrations in response to Perillyl alcohol $(\mathrm{POH})$ therapy through the use of a fluorometric method in patients with terminal stage glioblastoma and in patients with brain metastases from stage IV adenocarcinomas localized elsewhere. The patients were compared with a control group of healthy individuals. A dramatic rise in circulating DNA plasma levels was reported in patients with glioblastoma and brain metastases. Such an increase in the concentration of circulating DNA in the bloodstream can be explained by the damage of the BBB present at this stage of the disease [119]. It would be expected that the pre-apoptotic effect of $\mathrm{POH}$ would increase the level of apoptotic DNA. However, the authors reported a decrease in circulating DNA levels and an increase in life expectancy, given that the MRI pattern was equivalent to a full response to therapy. It is possible that the level of blood DNAses increases, or the level of their inhibitors decreases, under the influence of anticancer therapy. Discontinuation of the drug treatment caused an increase in the circulating DNA levels. The observed levels of blood circulating DNA are in contrast with the findings of other research groups, which reported very low brain-tumor derived DNA present in the blood (less than 0.01\%) [9]. Since the source of circulating DNA is not established in this case due to the use of the fluorimetric method, the origin of circulating DNA remains in question. Nevertheless, in spite of the obscure origin, the amount of circulating DNA can still serve as a marker of the effectiveness of therapy. 
As previously mentioned regarding circulating Alu methylated sequences, some studies demonstrated heterogeneity in ctDNA amounts obtained from glioblastoma patients at different tumor stages. More generally, Chetan Bettegowda and coworkers evaluated the concentration of ctDNA in 640 patients with various cancer types, including glioblastoma, and at different stages (metastatic or localized). Overall, the PCR-based methods used showed that $>75 \%$ of patients with advanced tumors harbor mutant DNA fragments, while ctDNA was found in less than $50 \%$ of patients with primary tumors, especially those patients with brain tumors, of which the majority of samples were early-stage tumors [31].

Regarding studies performed exclusively on glioma patients at different stages, Piccioni D.E. and colleagues published a biggest study aimed at evaluating the clinical usefulness of ctDNA analysis. They analyzed 419 primary brain tumors, including 370 astrocytic and oligodendroglial tumors (of which 222 were glioblastoma) [208]. Among the several results obtained, the authors demonstrated that ctDNA mutations rate increased significantly with the more advanced astrocytic and oligodendroglial tumor grades, ranging from $20 \%$ of positive grade I samples to $55 \%$ of grade IV samples ( $28 \%$ grade II and $40 \%$ grade III) [208].

These results confirmed that ctDNA can be more easily identified in higher-grade brain tumors compared to lower-grade tumors. Therefore, ctDNA analysis represents a useful tool for monitoring these patients. Concerning the low-grade tumors, alterations in the circulating DNA are found only in a low percentage of patients. Therefore, the analysis of ctDNA alone may not be sufficient to effectively diagnose tumors at their initial stage. In this case, this analysis must be coupled with the current diagnostics strategies based on imaging techniques.

\section{Urinary Circulating DNA in Urological Tumors}

It was shown that ctDNA was detected in $50 \%$ of plasma and in $70 \%$ of urine samples from patients with renal cell carcinoma (RCC), prostate cancer (PCa), and bladder carcinoma (BC) [209]. Regarding RCC, ctDNA studies are still in their infancy, but there are many promising roles for both localized and metastatic renal cell carcinoma [210]. ctDNA detection in the plasma of patients with metastatic PCa has paved the way for developing biomarkers, given the impossibility of metastatic tissue sampling. Using liquid biopsies, resistance to androgen receptor (AR)-targeted therapy has been linked to the amplification/mutation of $A R$ gene and the expression of truncated splice variants which display ligand-independent activity [47-49,211-215]. Therefore, it appears that ctDNA detection is increasingly incorporated into the design of clinical trials with a potential of being integrated into routine patient care. Importantly, ctDNA detection will help to understand PCa development at molecular level and will help lead the way toward a better prognosis and treatment selection, especially with the goal of elucidating tumor resistance mechanisms [216].

In the case of BC, the total pool of circulating DNA in urine was significantly increased in patients compared with the control group [217]. Furthermore, the fragment length of such ctDNA in urine is much greater in patients than in healthy controls [218]. This fact suggests that ctDNA originates from a necrotic tumor, or surrounding tissues that are forced to die under the influence of the tumor-specific molecular signaling [218]. It has been reported that the methylation pattern of POU4F2 and PCDH17 in urine ctDNA allows for the discrimination between patients with bladder cancer and patients with other urological conditions compared with healthy volunteers, with $90 \%$ sensitivity and $94 \%$ specificity [19]. Methylation profiles of TWIST1 and NID2 in urine ctDNA allow the identification of patients with a primary tumor with a sensitivity of $90 \%$ and a specificity of $93 \%$ [219-221].

Similar to CancerSEEK, a method for screening upper and lower urinary tract urothelial tumors has been developed for large-scale urothelial DNA analysis in urine (called UroSEEK) [222,223]. The test incorporates massive parallel sequencing assays for mutations in 11 genes, including mutations in the TERT gene promoter (a hard-to-amplify region, with high GC content), aneuploidy analysis, and copy number changes on 11 gene mutations localized on 39 chromosome arms. This study does not discuss ctDNA, and instead focuses on DNA derived from urothelial cells released in urine samples. 
However, this method could be easily translated to ctDNA detection. In fact, in a recent study, genomic profiles of urine cell DNA, urine circulating DNA, and DNA from paraffin-embedded samples of 23 well-characterized tumors of patients with $\mathrm{BC}$ were compared [13]. The data showed that urine ctDNA patterns correspond with the tumor tissue DNA patterns and have a greater load than the DNA obtained from the urothelium (which is typical for tumor genome) $(P<0.001)$. Consequently, ctDNA has a higher analytical sensitivity for the detection of clinically significant genomic aberrations $(P<0.04)$. It is assumed that the increased tumor genome in ctDNA might be the result of a higher rate of tumor cell necrosis in urine, relative to normal urothelium [13].

As described in the previous paragraph, the study of Bettegowda C. showed an increase of ctDNA levels in high-grade tumors compared to low-grade ones. However, this study contained a limited number of urological samples [31].

Taking into account studies analyzing urological cancers only, Christensen E. and collaborators studied the plasma and urine samples presence of PIK3CA and FGFR3 mutations in more than 800 bladder cancer patients with both non-muscle-invasive bladder cancer (NMIBC) and radical cystectomy following muscle-invasive bladder cancer (MIBC) [148]. As opposite to what has been described for glioblastoma, in this study, the authors showed that patients with low-grade tumors (NMIBC) had a $36 \%$ circulating mutation rate compared to patients with high grade-tumors (MIBC), who had a percentage of $11 \%$ of ctDNA positivity [148]. These data can be explained because the patients having cystectomies performed right after MIBC diagnosis theoretically do no longer have the tumor mass. Therefore, they cannot release any ctDNA into the bloodstream or urine. However, an interesting reported finding was that patients with cystectomy and positive for PIK3CA and FGFR 3 circulating mutations had a higher incidence of tumor recurrence [148]. Therefore, in this case, the liquid biopsy can also provide useful information to the clinician to predict the patient's prognosis and to identify early tumors which will give rise to recurrence or potentially will evolve from NMIBC to MIBC.

\section{Multiplex Genotyping Based on ctDNA Mass-Spectrometry}

Although, at present, the leading approach for the characterization of ctDNA is the NGS approach, other methods based on mass spectrometry are being developed. Short oligonucleotide mass analysis (SOMA) was proposed in the early 2000s for the study of ctDNA in plasma and in urine [51]. The use of the HPLC protocol ESI-MS-SOMA allowed for the differentiation between patients with hepatocarcinoma and patients with liver cirrhosis or healthy individuals by monitoring the mutation in the 249 codons of the TP53 gene [51]. The method was not widely used and its application was limited to the characterization of plasma tumor DNA in hepatocarcinoma, although it was characterized as a sensitive technique for detecting mutations. Further developments led to the use of high-resolution mass spectrometry methods with Matrix-assisted laser desorption/ionization time-of-flight-mass spectrometry (MALDI-TOF-MS) [59,224]. The advantage of MALDI is the formation of singly charged oligonucleotide ions, the separation of which depends on the structure of the analyte and the restriction enzyme used. In addition, the advantage of TOF detection is the ability to measure masses in excess of $100 \mathrm{kDa}$. Sequencing is performed by calculating the mass difference between adjacent signals, and the interpretation of the spectra of multicomponent samples is not difficult. Comparison of the signal intensity between the four mass spectra allows the determination of the initial sequence [59]. For that features, MALDI-TOF-MS enables multiplex genotyping and is considered a sensitive, reliable, fast, and cost-effective technology for detecting target mutations in NSCLC patients [225]. MS analysis was used to test 158 mutations of major EGFR, KRAS, BRAF, ALK, PIK3CA, ERBB2, DDR2, AKT, and MEK1 oncogenes in 92 NSCLC tumor samples and in 13 plasma samples. Also, cytological samples have been analyzed. Those samples are often a unique source of the original tumor material, but are of poorer quality for different molecular studies. It was observed that a mutated allele with a frequency higher than $10 \%$, was positively detected even with a small amount of DNA $(5 \mathrm{ng})$. With less than $10 \%$ of mutated allele, the detection must be performed with 10ng of DNA as starting material. The authors do not recommend the use of molecular diagnostics for the analysis of low-quality samples, with less 
than $20 \%$ of tumor within the whole sample. MS is recommended as an alternative high-performance method for detecting known mutations, even in the case of low-quality samples. It allows genotyping the deficient component of ctDNA in a tissue sample, which has an important impact on the clinical management of the patient [225].

\section{Limitations of the Use of ctDNA in Cancer Routine Practice}

With the progressive development of methods for studying extracellular tumor DNA, the wide clinical application of this technology will occur in a matter of time. The main drawback is genetic heterogeneity and high mutagenesis of tumors [226]. During disease progression, individual disseminated tumor cells and metastases may acquire characteristics different from those of primary tumors [32]. Moreover, although in some cases (melanomas) the mutational status is strictly associated with the anatomical type and localization of the tumor [227], many mutations are secondary and they may be lost by tumor clones during tumor recurrence. Phenotypically similar tumors may include quite different molecular genotypes, representing the individuality of each tumor and each patient [228]. The dynamic and heterogeneous nature of the tumor mass is characterized by pronounced genomic instability, somatic mutations, and epigenetic changes and, despite the advancement of surgical, radiological and pharmacological treatment, is worsened following cytotoxic chemotherapy and ionizing radiation therapy $[66,119,229]$. It still remains under question whether a mutational status might represent a valid basis for the selection a personalized type of therapy (oncogenic driver mutations) or whether it might be used only as a diagnostic tool [230]. Consensus at the Food and Drug Administration (FDA) level has only been reached for the treatment of tumors with certain mutations of the DNA repair systems (and, as a result, microsatellite instability), coupled with pembrolizumab (checkpoint blockade) based-therapy. This is the first case where it is not the anatomical location of a tumor, but its genetic features to dictate the selected immunotherapy to be chosen for the patient [231].

The limitations of the ctDNA approach are summarized in the comments of various authors concerning CancerSEEK methodology:

- $\quad$ The majority of patients in the study had stage II-III of disease, which does not yet provide an opportunity to assess the applicability of the test for early diagnosis [232].

- As control, the authors analyzed the urine of only healthy individuals. Thus, the high specificity of the CancerSeek approach requires further validation with non-cancer control with associated diseases, such as inflammatory diseases of the genitourinary system, which are common in the elderly [233].

- The limitations of the method are linked with the same heterogeneity of tumors, such as lung cancer [234]. These circumstances cannot be attributed to the shortcomings of the method, but make it necessary to add additional markers that may increase the accuracy of the study, such as RNA of exosomes for early diagnosis of non-small cell lung cancer [235].

The authors themselves state that the CancerSEEK does not work equally for all cancers. The panel achieved a total median sensitivity of $70 \%$ with a specificity of $\geq 99 \%$, but significant differences in sensitivity were observed between the different types of tumors analyzed (e.g., $98 \%$ for ovarian cancer, $60 \%$ for lung cancer, and only $33 \%$ for breast cancer) [36].

In general, most of the available studies cover narrow areas of the wide oncology field, they analyze only specific types of tumors and they need to be confirmed on larger patient cohorts.

\section{Conclusions}

Used as primary oncologic screening, liquid biopsy represents a valid alternative to tissue biopsy which allows the clinicians to focus on the most common, early, and stable markers, coupled with a specific the oncologic process. Such liquid biopsy allows doctors to perform the therapeutic profiling of cancer patients to monitor the anticancer therapy efficacy, as well as to predict the progression of an 
already identified cancer. In this way, it is possible to identify fine alterations of markers specific for each patient [35].

This review can be summarized with the words of Bert Vogelstein, MD, Clayton Professor of Oncology and Howard Hughes Medical Institute researcher: "If we are going to make progress in early cancer detection, we have to begin looking at it in a more realistic way, recognizing that no test will detect all cancers" [236].

Supplementary Materials: The following are available online at http://www.mdpi.com/2073-4409/8/10/1251/s1.

Author Contributions: Conceptualization: A.T., M.L., D.A.S. and C.M.; Writing-Original Draft Preparation: N.O.T., L.F., Y.B.P., A.E.N. and G.T.; Figures and Tables: V.M.T., L.K. and N.D.; Writing-Review \& Editing: N.O.T., L.F., Y.B.P, A.E.N., V.M.T., L.K., D.A.S., N.D., A.K., C.M., G.T., M.L. and A.T.; Final revisions: L.F., N.O.T, A.K., N.D., A.T. All authors have approved the final version of the manuscript.

Funding: This research was funded by I.M. Sechenov First Moscow State Medical University Strategic Development Program under the Russian Academic Excellence 5-100 Project.

Conflicts of Interest: The authors declare no conflict of interest.

\section{References}

1. Kustanovich, A.; Schwartz, R.; Peretz, T.; Grinshpun, A. Life and death of circulating cell-free DNA. Cancer Biol. Ther. 2019, 20, 1057-1067. [CrossRef]

2. Thierry, A.R.; El Messaoudi, S.; Gahan, P.B.; Anker, P.; Stroun, M. Origins, structures, and functions of circulating DNA in oncology. Cancer Metastasis Rev. 2016, 35, 347-376. [CrossRef]

3. Aucamp, J.; Bronkhorst, A.J.; Badenhorst, C.P.; Pretorius, P.J. A historical and evolutionary perspective on the biological significance of circulating DNA and extracellular vesicles. Cell Mol. Life Sci. 2016, 73, 4355-4381. [CrossRef]

4. Zhang, Y.; Liu, Y.; Liu, H.; Tang, W.H. Exosomes: Biogenesis, biologic function and clinical potential. Cell Biosci. 2019, 9, 19. [CrossRef]

5. Nielsen, K.M.; Johnsen, P.J.; Bensasson, D.; Daffonchio, D. Release and persistence of extracellular DNA in the environment. Env. Biosaf. Res. 2007, 6, 37-53. [CrossRef]

6. Jiang, P.; Lo, Y.M.D. The Long and Short of Circulating Cell-Free DNA and the Ins and Outs of Molecular Diagnostics. Trends Genet. 2016, 32, 360-371. [CrossRef]

7. Zhang, L.; Liang, Y.; Li, S.; Zeng, F.; Meng, Y.; Chen, Z.; Liu, S.; Tao, Y.; Yu, F. The interplay of circulating tumor DNA and chromatin modification, therapeutic resistance, and metastasis. Mol. Cancer 2019, 18, 36. [CrossRef]

8. Kosovec, J.E.; Zaidi, A.H.; Pounardjian, T.S.; Jobe, B.A. The Potential Clinical Utility of Circulating Tumor DNA in Esophageal Adenocarcinoma: From Early Detection to Therapy. Front. Oncol. 2018, 8, 610. [CrossRef]

9. Wang, J.; Bettegowda, C. Applications of DNA-based liquid biopsy for central nervous system neoplasms. J. Mol. Diagn. 2017, 19, 24-34. [CrossRef]

10. Bronkhorst, A.J.; Wentzel, J.F.; Aucamp, J.; van Dyk, E.; du Plessis, L.; Pretorius, P.J. Characterization of the cell-free DNA released by cultured cancer cells. Biochim. Biophys. Acta 2016, 1863, 157-165. [CrossRef]

11. Hyun, K.A.; Koo, G.B.; Han, H.; Sohn, J.; Choi, W.; Kim, S.I.; Jung, H.I.; Kim, Y.S. Epithelial-to-mesenchymal transition leads to loss of EpCAM and different physical properties in circulating tumor cells from metastatic breast cancer. Oncotarget 2016, 7, 24677-24687. [CrossRef]

12. Au, S.H.; Storey, B.D.; Moore, J.C.; Tang, Q.; Chen, Y.L.; Javaid, S.; Sarioglu, A.F.; Sullivan, R.; Madden, M.W.; O'Keefe, R.; et al. Clusters of circulating tumor cells traverse capillary-sized vessels. Proc. Natl. Acad. Sci. USA 2016, 113, 4947-4952. [CrossRef]

13. Togneri, F.S.; Ward, D.G.; Foster, J.M.; Devall, A.J.; Wojtowicz, P.; Alyas, S.; Vasques, F.R.; Oumie, A.; James, N.D.; Cheng, K.K.; et al. Genomic complexity of urothelial bladder cancer revealed in urinary cfDNA. Eur. J. Hum. Genet. 2016, 24, 1167-1174. [CrossRef]

14. Heitzer, E.; Ulz, P.; Belic, J.; Gutschi, S.; Quehenberger, F.; Fischereder, K.; Benezeder, T.; Auer, M.; Pischler, C.; Mannweiler, S.; et al. Tumor-associated copy number changes in the circulation of patients with prostate cancer identified through whole-genome sequencing. Genome Med. 2013, 5, 30. [CrossRef] 
15. Salvi, S.; Casadio, V.; Conteduca, V.; Burgio, S.L.; Menna, C.; Bianchi, E.; Rossi, L.; Carretta, E.; Masini, C.; Amadori, D.; et al. Circulating cell-free AR and CYP17A1 copy number variations may associate with outcome of metastatic castration-resistant prostate cancer patients treated with abiraterone. Br. J. Cancer 2015, 112, 1717-1724. [CrossRef]

16. Schütz, E.; Akbari, M.R.; Beck, J.; Urnovitz, H.; Zhang, W.W.; Bornemann-Kolatzki, K.; Mitchell, W.M.; Nam, R.K.; Narod, S.A. Chromosomal instability in cell-free DNA is a serum biomarker for prostate cancer. Clin. Chem. 2015, 61, 239-248. [CrossRef]

17. Schwarzenbach, H.; Pantel, K. Circulating DNA as biomarker in breast cancer. Breast Cancer Res. 2015, 17, 136. [CrossRef]

18. Falzone, L.; Lupo, G.; La Rosa, G.R.M.; Crimi, S.; Anfuso, C.D.; Salemi, R.; Rapisarda, E.; Libra, M.; Candido, S. Identification of Novel MicroRNAs and Their Diagnostic and Prognostic Significance in Oral Cancer. Cancers 2019, 11, 610. [CrossRef]

19. Wang, Y.; Yu, Y.; Ye, R.; Zhang, D.; Li, Q.; An, D.; Fang, L.; Lin, Y.; Hou, Y.; Xu, A.; et al. An epigenetic biomarker combination of PCDH17 and POU4F2 detects bladder cancer accurately by methylation analyses of urine sediment DNA in Han Chinese. Oncotarget 2016, 7, 2754-2764. [CrossRef]

20. Falzone, L.; Salemi, R.; Travali, S.; Scalisi, A.; McCubrey, J.A.; Candido, S.; Libra, M. MMP-9 overexpression is associated with intragenic hypermethylation of MMP9 gene in melanoma. Aging 2016, 8, 933-944. [CrossRef]

21. Marzese, D.M.; Hirose, H.; Hoon, D.S. Diagnostic and prognostic value of circulating tumor-related DNA in cancer patients. Expert Rev. Mol. Diagn. 2013, 13, 827-844. [CrossRef]

22. Snyder, M.W.; Kircher, M.; Hill, A.J.; Daza, R.M.; Shendure, J. Cell-free DNA Comprises an In Vivo Nucleosome Footprint that Informs Its Tissues-Of-Origin. Cell 2016, 164, 57-68. [CrossRef]

23. Sharma, S.; Kelly, T.K.; Jones, P.A. Epigenetics in cancer. Carcinogenesis 2010, 31, 27-36. [CrossRef]

24. Laird, P.W. Early detection: The power and the promise of DNA methylation markers. Nat. Rev. Cancer 2003, 3, 253-266. [CrossRef]

25. Chu, D.; Park, B.H. Liquid biopsy: Unlocking the potentials of cell-free DNA. Virchows Archiv. 2017, 471, 147-154. [CrossRef]

26. Macías, M.; Alegre, E.; Díaz-Lagares, A.; Patiño, A.; Pérez-Gracia, J.L.; Sanmamed, M.; López-López, R.; Varo, N.; González, A. Liquid Biopsy: From Basic Research to Clinical Practice. Adv. Clin. Chem. 2018, 83, 73-119.

27. Rothé, F.; Laes, J.F.; Lambrechts, D.; Smeets, D.; Vincent, D.; Maetens, M.; Fumagalli, D.; Michiels, S.; Drisis, S.; Moerman, C.; et al. Plasma circulating tumor DNA as an alternative to metastatic biopsies for mutational analysis in breast cancer. Ann. Oncol. 2014, 25, 1959-1965. [CrossRef]

28. Elazezy, M.; Joosse, S.A. Techniques of using circulating tumor DNA as a liquid biopsy component in cancer management. Comput. Struct. Biotechnol. J. 2018, 16, 370-378. [CrossRef]

29. Palmirotta, R.; Lovero, D.; Cafforio, P.; Felici, C.; Mannavola, F.; Pellè, E.; Quaresmini, D.; Tucci, M.; Silvestris, F. Liquid biopsy of cancer: A multimodal diagnostic tool in clinical oncology. Adv. Med. Oncol. 2018, 10, 1758835918794630. [CrossRef]

30. Fiala, C.; Diamandis, E.P. Utility of circulating tumor DNA in cancer diagnostics with emphasis on early detection. BMC Med. 2018, 16, 166. [CrossRef]

31. Bettegowda, C.; Sausen, M.; Leary, R.J.; Kinde, I.; Wang, Y.; Agrawal, N.; Bartlett, B.R.; Wang, H.; Luber, B.; Alani, R.M.; et al. Detection of circulating tumor DNA in early- and late-stage human malignancies. Sci. Transl. Med. 2014, 6, 224ra24. [CrossRef]

32. Khier, S.; Lohan, L. Kinetics of circulating cell-free DNA for biomedical applications: Critical appraisal of the literature. Future Sci. OA 2018, 4, FSO295. [CrossRef]

33. Di Meo, A.; Bartlett, J.; Cheng, Y.; Pasic, M.D.; Yousef, G.M. Liquid biopsy: A step forward towards precision medicine in urologic malignancies. Mol. Cancer 2017, 16, 80. [CrossRef]

34. Qin, Z.; Ljubimov, V.A.; Zhou, C.; Tong, Y.; Liang, J. Cell-free circulating tumor DNA in cancer. Chin. J. Cancer 2016, 35, 36. [CrossRef]

35. Riethdorf, S.; Soave, A.; Rink, M. The current status and clinical value of circulating tumor cells and circulating cell-free tumor DNA in bladder cancer. Transl. Androl. Urol. 2017, 6, 1090. [CrossRef]

36. Cohen, J.D.; Li, L.; Wang, Y.; Thoburn, C.; Afsari, B.; Danilova, L.; Douville, C.; Javed, A.A.; Wong, F.; Mattox, A.; et al. Detection and localization of surgically resectable cancers with a multi-analyte blood test. Science 2018, 359, 926-930. [CrossRef] 
37. Dawson, S.J.; Tsui, D.W.; Murtaza, M.; Biggs, H.; Rueda, O.M.; Chin, S.F.; Dunning, M.J.; Gale, D.; Forshew, T.; Mahler-Araujo, B.; et al. Analysis of circulating tumor DNA to monitor metastatic breast cancer. N. Engl. J. Med. 2013, 368, 1199-1209. [CrossRef]

38. Diehl, F.; Schmidt, K.; Choti, M.A.; Romans, K.; Goodman, S.; Li, M.; Thornton, K.; Agrawal, N.; Sokoll, L.; Szabo, S.A.; et al. Circulating mutant DNA to assess tumor dynamics. Nat. Med. 2008, 14, 985-990. [CrossRef]

39. Woff, E.; Kehagias, P.; Vandeputte, C.; Ameye, L.; Guiot, T.; Paesmans, M.; Hendlisz, A.; Flamen, P. Combining 18F-FDG PET/CT-based Metabolically Active Tumor Volume and Circulating Cell-free DNA Significantly Improves Outcome Prediction in Chemorefractory Metastatic Colorectal Cancer. J. Nucl. Med. 2019. [CrossRef]

40. Winther-Larsen, A.; Fledelius, J.; Demuth, C.; Bylov, C.M.; Meldgaard, P.; Sorensen, B.S. Early Change in FDG-PET Signal and Plasma Cell-Free DNA Level Predicts Erlotinib Response in EGFR Wild-Type NSCLC Patients. Transl. Oncol. 2016, 9, 505-511. [CrossRef]

41. Nygaard, A.D.; Holdgaard, P.C.; Spindler, K.L.; Pallisgaard, N.; Jakobsen, A. The correlation between cell-free DNA and tumour burden was estimated by PET/CT in patients with advanced NSCLC. Br. J. Cancer 2014, 110, 363-368. [CrossRef]

42. Jia, N.; Sun, Z.; Gao, X.; Cheng, Y.; Zhou, Y.; Shen, C.; Chen, W.; Wang, X.; Shi, R.; Li, N.; et al. Serial Monitoring of Circulating Tumor DNA in Patients With Metastatic Colorectal Cancer to Predict the Therapeutic Response. Front. Genet. 2019, 10, 470. [CrossRef]

43. Siravegna, G.; Mussolin, B.; Venesio, T.; Marsoni, S.; Seoane, J.; Dive, C.; Papadopoulos, N.; Kopetz, S.; Corcoran, R.B.; Siu, L.L.; et al. How liquid biopsies can change clinical practice in oncology. Ann. Oncol. 2019. [CrossRef]

44. Finotti, A.; Allegretti, M.; Gasparello, J.; Giacomini, P.; Spandidos, D.A.; Spoto, G.; Gambari, R. Liquid biopsy and PCR-free ultrasensitive detection systems in oncology (Review). Int. J. Oncol. 2018, 53, 1395-1434. [CrossRef]

45. Forshew, T.; Murtaza, M.; Parkinson, C.; Gale, D.; Tsui, D.W.; Kaper, F.; Dawson, S.J.; Piskorz, A.M.; Jimenez-Linan, M.; Bentley, D.; et al. Noninvasive identification and monitoring of cancer mutations by targeted deep sequencing of plasma DNA. Sci. Transl. Med. 2012, 4, 136ra68. [CrossRef]

46. Zill, O.A.; Greene, C.; Sebisanovic, D.; Siew, L.M.; Leng, J.; Vu, M.; Hendifar, A.E.; Wang, Z.; Atreya, C.E.; Kelley, R.K.; et al. Cell-Free DNA Next-Generation Sequencing in Pancreatobiliary Carcinomas. Cancer Discov. 2015, 5, 1040-1048. [CrossRef]

47. Annala, M.; Vandekerkhove, G.; Khalaf, D.; Taavitsainen, S.; Beja, K.; Warner, E.W.; Sunderland, K.; Kollmannsberger, C.; Eigl, B.J.; Finch, D.; et al. Circulating Tumor DNA Genomics Correlate with Resistance to Abiraterone and Enzalutamide in Prostate Cancer. Cancer Discov. 2018, 8, 444-457. [CrossRef]

48. Conteduca, V.; Wetterskog, D.; Sharabiani, M.T.A.; Grande, E.; Fernandez-Perez, M.P.; Jayaram, A.; Salvi, S.; Castellano, D.; Romanel, A.; Lolli, C.; et al. Androgen receptor gene status in plasma DNA associates with worse outcome on enzalutamide or abiraterone for castration-resistant prostate cancer: A multi-institution correlative biomarker study. Ann. Oncol. 2017, 28, 1508-1516. [CrossRef]

49. Wyatt, A.W.; Azad, A.A.; Volik, S.V.; Annala, M.; Beja, K.; McConeghy, B.; Haegert, A.; Warner, E.W.; Mo, F.; Brahmbhatt, S.; et al. Genomic Alterations in Cell-Free DNA and Enzalutamide Resistance in Castration-Resistant Prostate Cancer. JAMA Oncol. 2016, 2, 1598-1606. [CrossRef]

50. Ade, C.; Roy-Engel, A.M.; Deininger, P.L. Alu elements: An intrinsic source of human genome instability. Curr. Opin. Virol. 2013, 3, 639-645. [CrossRef]

51. Szymañska, K.; Chen, J.G.; Cui, Y.; Gong, Y.Y.; Turner, P.C.; Villar, S.; Wild, C.P.; Parkin, D.M.; Hainaut, P. TP53 R249S mutations, exposure to aflatoxin, and occurrence of hepatocellular carcinoma in a cohort of chronic hepatitis B virus carriers from Qidong, China. Cancer Epidemiol. Biomarkers Prev. 2009, 18, 1638-1643. [CrossRef]

52. Shaw, J.A.; Page, K.; Blighe, K.; Hava, N.; Guttery, D.; Ward, B.; Brown, J.; Ruangpratheep, C.; Stebbing, J.; Payne, R.; et al. Genomic analysis of circulating cell-free DNA infers breast cancer dormancy. Genome Res. 2012, 22, 220-231. [CrossRef]

53. Olsson, E.; Winter, C.; George, A.; Chen, Y.; Howlin, J.; Tang, M.H.; Dahlgren, M.; Schulz, R.; Grabau, D.; van Westen, D.; et al. Serial monitoring of circulating tumor DNA in patients with primary breast cancer for detection of occult metastatic disease. EMBO Mol. Med. 2015, 7, 1034-1047. [CrossRef] 
54. Kawakami, H.; Okamoto, I.; Arao, T.; Okamoto, W.; Matsumoto, K.; Taniguchi, H.; Kuwata, K.; Yamaguchi, H.; Nishio, K.; Nakagawa, K.; et al. MET amplification as a potential therapeutic target in gastric cancer. Oncotarget 2013, 4, 9-17. [CrossRef]

55. Shoda, K.; Ichikawa, D.; Fujita, Y.; Masuda, K.; Hiramoto, H.; Hamada, J.; Arita, T.; Konishi, H.; Komatsu, S.; Shiozaki, A.; et al. Monitoring the HER2 copy number status in circulating tumor DNA by droplet digital PCR in patients with gastric cancer. Gastric Cancer 2017, 20, 126-135. [CrossRef]

56. Leary, R.J.; Sausen, M.; Kinde, I.; Papadopoulos, N.; Carpten, J.D.; Craig, D.; O’Shaughnessy, J.; Kinzler, K.W.; Parmigiani, G.; Vogelstein, B.; et al. Detection of chromosomal alterations in the circulation of cancer patients with whole-genome sequencing. Sci. Transl. Med. 2012, 4, 162ra154. [CrossRef]

57. Leary, R.J.; Kinde, I.; Diehl, F.; Schmidt, K.; Clouser, C.; Duncan, C.; Antipova, A.; Lee, C.; McKernan, K.; De La Vega, F.M.; et al. Development of personalized tumor biomarkers using massively parallel sequencing. Sci. Transl. Med. 2010, 2, 20ra14. [CrossRef]

58. Newman, A.M.; Bratman, S.V.; To, J.; Wynne, J.F.; Eclov, N.C.; Modlin, L.A.; Liu, C.L.; Neal, J.W.; Wakelee, H.A.; Merritt, R.E.; et al. An ultrasensitive method for quantitating circulating tumor DNA with broad patient coverage. Nat. Med. 2014, 20, 548-554. [CrossRef]

59. Gao, X.; Tan, B.H.; Sugrue, R.J.; Tang, K. MALDI mass spectrometry for nucleic acid analysis. In Applications of MALDI-TOF Spectroscopy; Springer: Berlin/Heidelberg, Germany, 2012; pp. 55-77.

60. Patel, K.M.; van der Vos, K.E.; Smith, C.G.; Mouliere, F.; Tsui, D.; Morris, J.; Chandrananda, D.; Marass, F.; van den Broek, D.; Neal, D.E.; et al. Association Of Plasma And Urinary Mutant DNA With Clinical Outcomes In Muscle Invasive Bladder Cancer. Sci. Rep 2017, 7, 5554. [CrossRef]

61. Wan, J.C.M.; Massie, C.; Garcia-Corbacho, J.; Mouliere, F.; Brenton, J.D.; Caldas, C.; Pacey, S.; Baird, R.; Rosenfeld, N. Liquid biopsies come of age: Towards implementation of circulating tumour DNA. Nat. Rev. Cancer 2017, 17, 223-238. [CrossRef]

62. Wood-Bouwens, C.M.; Ji, H.P. Single Color Multiplexed ddPCR Copy Number Measurements and Single Nucleotide Variant Genotyping. In Digital PCR; Humana Press: New York, NY, USA, 2018; pp. 323-333.

63. Schiffman, J.D.; Fisher, P.G.; Gibbs, P. Early detection of cancer: Past, present, and future. Am. Soc. Clin. Oncol. Educ. Book 2015, 57-65. [CrossRef]

64. Gates, T.J. Screening for cancer: Concepts and controversies. Am. Fam. Physician 2014, 90, 625-631. [CrossRef]

65. Smith, R.A.; Andrews, K.S.; Brooks, D.; Fedewa, S.A.; Manassaram-Baptiste, D.; Saslow, D.; Brawley, O.W.; Wender, R.C. Cancer screening in the United States, 2018: A review of current American Cancer Society guidelines and current issues in cancer screening. CA Cancer J. Clin. 2018, 68, 297-316. [CrossRef]

66. Falzone, L.; Salomone, S.; Libra, M. Evolution of Cancer Pharmacological Treatments at the Turn of the Third Millennium. Front. Pharmacol. 2018, 9, 1300. [CrossRef]

67. Bai, Y.; Zhao, H. Liquid biopsy in tumors: Opportunities and challenges. Ann. Transl. Med. 2018, 6, S89. [CrossRef]

68. Shendure, J.; Ji, H. Next-generation DNA sequencing. Nat. Biotechnol. 2008, 26, 1135-1145. [CrossRef]

69. Anderson, M.W.; Schrijver, I. Next generation DNA sequencing and the future of genomic medicine. Genes 2010, 1, 38-69. [CrossRef]

70. Lanman, R.B.; Mortimer, S.A.; Zill, O.A.; Sebisanovic, D.; Lopez, R.; Blau, S.; Collisson, E.A.; Divers, S.G.; Hoon, D.S.; Kopetz, E.S.; et al. Analytical and Clinical Validation of a Digital Sequencing Panel for Quantitative, Highly Accurate Evaluation of Cell-Free Circulating Tumor DNA. PLoS ONE 2015, 10, e0140712. [CrossRef]

71. Haber, D.A.; Velculescu, V.E. Blood-based analyses of cancer: Circulating tumor cells and circulating tumor DNA. Cancer Discov. 2014, 4, 650-661. [CrossRef]

72. Ignatiadis, M.; Dawson, S.J. Circulating tumor cells and circulating tumor DNA for precision medicine: Dream or reality? Ann. Oncol. 2014, 25, 2304-2313. [CrossRef]

73. Murtaza, M.; Dawson, S.J.; Tsui, D.W.; Gale, D.; Forshew, T.; Piskorz, A.M.; Parkinson, C.; Chin, S.F.; Kingsbury, Z.; Wong, A.S.; et al. Non-invasive analysis of acquired resistance to cancer therapy by sequencing of plasma DNA. Nature 2013, 497, 108-112. [CrossRef]

74. Arakelyan, A.S.; Galeeva, A.K.; Sushhentsev, N.A.; Degtyarevskaya, T.Y.; Chebyshev, N.V. Prospects for the study of circulating in the blood of tumor DNA as a marker of the state of malignant tumors. In Proceedings of the XXII Youth Scientific Forum: Natural and Medical Sciences, Moscow, Russia, 13-17 April 2015. 
75. Kinde, I.; Wu, J.; Papadopoulos, N.; Kinzler, K.W.; Vogelstein, B. Detection and quantification of rare mutations with massively parallel sequencing. Proc. Natl. Acad. Sci. USA 2011, 108, 9530-9535. [CrossRef]

76. Maru, Y.; Tanaka, N.; Ohira, M.; Itami, M.; Hippo, Y.; Nagase, H. Identification of novel mutations in Japanese ovarian clear cell carcinoma patients using optimized targeted NGS for clinical diagnosis. Gynecol. Oncol. 2017, 144, 377-383. [CrossRef]

77. Mehrotra, M.; Singh, R.R.; Chen, W.; Huang, R.S.P.; Almohammedsalim, A.A.; Barkoh, B.A.; Simien, C.M.; Hernandez, M.; Behrens, C.; Patel, K.P.; et al. Study of Preanalytic and Analytic Variables for Clinical Next-Generation Sequencing of Circulating Cell-Free Nucleic Acid. J. Mol. Diagn. 2017, 19, 514-524. [CrossRef]

78. Kameta, E.; Sugimori, K.; Kaneko, T.; Ishii, T.; Miwa, H.; Sato, T.; Ishii, Y.; Sue, S.; Sasaki, T.; Yamashita, Y.; et al. Diagnosis of pancreatic lesions collected by endoscopic ultrasound-guided fine-needle aspiration using next-generation sequencing. Oncol. Lett. 2016, 12, 3875-3881. [CrossRef]

79. Kaiserm, J. 'Liquid biopsy' for cancer promises early detection. Science 2018, 359, 259. [CrossRef]

80. Postel, M.; Roosen, A.; Laurent-Puig, P.; Taly, V.; Wang-Renault, S.F. Droplet-based digital PCR and next generation sequencing for monitoring circulating tumor DNA: A cancer diagnostic perspective. Expert Rev. Mol. Diagn. 2018, 18, 7-17. [CrossRef]

81. Xu, T.; Kang, X.; You, X.; Dai, L.; Tian, D.; Yan, W.; Yang, Y.; Xiong, H.; Liang, Z.; Zhao, G.Q.; et al. Cross-Platform Comparison of Four Leading Technologies for Detecting EGFR Mutations in Circulating Tumor DNA from Non-Small Cell Lung Carcinoma Patient Plasma. Theranostics 2017, 7, 1437-1446. [CrossRef]

82. Battaglia, R.; Palini, S.; Vento, M.E.; La Ferlita, A.; Lo Faro, M.J.; Caroppo, E.; Borzì, P.; Falzone, L.; Barbagallo, D.; Ragusa, M.; et al. Identification of extracellular vesicles and characterization of miRNA expression profiles in human blastocoel fluid. Sci. Rep. 2019, 9, 84. [CrossRef]

83. McEvoy, A.C.; Warburton, L.; Al-Ogaili, Z.; Celliers, L.; Calapre, L.; Pereira, M.R.; Khattak, M.A.; Meniawy, T.M.; Millward, M.; Ziman, M.; et al. Correlation between circulating tumour DNA and metabolic tumour burden in metastatic melanoma patients. BMC Cancer 2018, 18, 726. [CrossRef]

84. Zhang, R.; Chen, B.; Tong, X.; Wang, Y.; Wang, C.; Jin, J.; Tian, P.; Li, W. Diagnostic accuracy of droplet digital PCR for detection of EGFR T790M mutation in circulating tumor DNA. Cancer Manag. Res. 2018, 10, 1209-1218. [CrossRef]

85. Van Ginkel, J.H.; Huibers, M.M.H.; van Es, R.J.J.; de Bree, R.; Willems, S.M. Droplet digital PCR for detection and quantification of circulating tumor DNA in plasma of head and neck cancer patients. BMC Cancer 2017, 17, 428. [CrossRef]

86. Medford, A.J.; Gillani, R.N.; Park, B.H. Detection of Cancer DNA in Early Stage and Metastatic Breast Cancer Patients. Methods Mol. Biol. 2018, 1768, 209-227.

87. Lund, H.L.; Hughesman, C.B.; McNeil, K.; Clemens, S.; Hocken, K.; Pettersson, R.; Karsan, A.; Foster, L.J.; Haynes, C. Initial diagnosis of chronic myelogenous leukemia based on quantification of M-BCR status using droplet digital PCR. Anal. Bioanal. Chem. 2016, 408, 1079-1094. [CrossRef]

88. Rapisarda, V.; Ledda, C.; Matera, S.; Fago, L.; Arrabito, G.; Falzone, L.; Marconi, A.; Libra, M.; Loreto, C. Absence of $\mathrm{t}(14 ; 18)$ chromosome translocation in agricultural workers after short-term exposure to pesticides. Mol. Med. Rep. 2017, 15, 3379-3382. [CrossRef]

89. Fenga, C.; Gangemi, S.; Di Salvatore, V.; Falzone, L.; Libra, M. Immunological effects of occupational exposure to lead (Review). Mol. Med. Rep. 2017, 15, 3355-3360. [CrossRef]

90. Rapisarda, V.; Salemi, R.; Marconi, A.; Loreto, C.; Graziano, A.C.; Cardile, V.; Basile, M.S.; Candido, S.; Falzone, L.; Spandidos, D.A.; et al. Fluoro-edenite induces fibulin-3 overexpression in non-malignant human mesothelial cells. Oncol. Lett. 2016, 12, 3363-3367. [CrossRef]

91. Falzone, L.; Marconi, A.; Loreto, C.; Franco, S.; Spandidos, D.A.; Libra, M. Occupational exposure to carcinogens: Benzene, pesticides and fibers (Review). Mol. Med. Rep. 2016, 14, 4467-4474. [CrossRef]

92. Malfa, G.A.; Tomasello, B.; Sinatra, F.; Villaggio, G.; Amenta, F.; Avola, R.; Renis, M. "Reactive” response evaluation of primary human astrocytes after methylmercury exposure. J. Neurosci. Res. 2014, 92, 95-103. [CrossRef]

93. Vivarelli, S.; Salemi, R.; Candido, S.; Falzone, L.; Santagati, M.; Stefani, S.; Torino, F.; Banna, G.L.; Tonini, G.; Libra, M. Gut Microbiota and Cancer: From Pathogenesis to Therapy. Cancers 2019, 11, 38. [CrossRef]

94. Vivarelli, S.; Falzone, L.; Basile, M.S.; Nicolosi, D.; Genovese, C.; Libra, M.; Salmeri, M. Benefits of using probiotics as adjuvants in anticancer therapy (Review). World Ac. Sci. J. 2019, 1, 125-135. [CrossRef] 
95. Garozzo, A.; Falzone, L.; Rapisarda, V.; Marconi, A.; Cinà, D.; Fenga, C.; Spandidos, D.A.; Libra, M. The risk of HCV infection among health-care workers and its association with extrahepatic manifestations (Review). Mol. Med. Rep. 2017, 15, 3336-3339. [CrossRef]

96. Banna, G.L.; Torino, F.; Marletta, F.; Santagati, M.; Salemi, R.; Cannarozzo, E.; Falzone, L.; Ferraù, F.; Libra, M. Lactobacillus rhamnosus GG: An Overview to Explore the Rationale of Its Use in Cancer. Front. Pharmacol. 2017, 8, 603. [CrossRef]

97. Margina, D.; Nițulescu, G.; Ungurianu, A.; Mesnage, R.; Goumenou, M.; Sarigiannis, D.; Aschner, M.; Spandidos, D.; Renieri, E.; Hernández, A.; et al. Overview of the effects of chemical mixtures with endocrine disrupting activity in the context of real-life risk simulation (RLRS): An integrative approach (Review). World Ac. Sci. J. 2019, 1, 157-164. [CrossRef]

98. Tsatsakis, A.M.; Docea, A.O.; Tsitsimpikou, C. New challenges in risk assessment of chemicals when simulating real exposure scenarios; simultaneous multi-chemicals' low dose exposure. Food Chem. Toxicol. 2016, 96, 174-176. [CrossRef]

99. Tsatsakis, A.M.; Kouretas, D.; Tzatzarakis, M.N.; Stivaktakis, P.; Tsarouhas, K.; Golokhvast, K.S.; Rakitskii, V.N.; Tutelyan, V.A.; Hernandez, A.F.; Rezaee, R.; et al. Simulating real-life exposures to uncover possible risks to human health: A proposed consensus for a novel methodological approach. Hum. Exp. Toxicol. 2017, 36, 554-564. [CrossRef]

100. Tsatsakis, A.M.; Docea, A.O.; Calina, D.; Buga, A.M.; Zlatian, O.; Gutnikov, S.; Kostoff, R.N.; Aschner, M. Hormetic Neurobehavioral effects of low dose toxic chemical mixtures in real-life risk simulation (RLRS) in rats. Food Chem. Toxicol. 2019, 125, 141-149. [CrossRef]

101. Docea, A.O.; Goumenou, M.; Calina, D.; Arsene, A.L.; Dragoi, C.M.; Gofita, E.; Pisoschi, C.G.; Zlatian, O.; Stivaktakis, P.D.; Nikolouzakis, T.K.; et al. Adverse and hormetic effects in rats exposed for 12 months to low dose mixture of 13 chemicals: RLRS part III. Toxicol. Lett. 2019, 310, 70-91. [CrossRef]

102. Tsatsakis, A.; Docea, A.O.; Constantin, C.; Calina, D.; Zlatian, O.; Nikolouzakis, T.K.; Stivaktakis, P.D.; Kalogeraki, A.; Liesivuori, J.; Tzanakakis, G.; et al. Genotoxic, cytotoxic, and cytopathological effects in rats exposed for 18 months to a mixture of 13 chemicals in doses below NOAEL levels. Toxicol. Lett. 2019, 316, 154-170. [CrossRef]

103. Tsoukalas, D.; Fragkiadaki, P.; Docea, A.O.; Alegakis, A.K.; Sarandi, E.; Thanasoula, M.; Spandidos, D.A.; Tsatsakis, A.; Razgonova, M.P.; Calina, D. Discovery of potent telomerase activators: Unfolding new therapeutic and anti-aging perspectives. Mol. Med. Rep. 2019. [CrossRef]

104. Greco, F.A.; Hainsworth, J.D. Introduction: Unknown primary cancer. Semin. Oncol. 2009, 36, 6-7. [CrossRef]

105. Snyder, T.M.; Khush, K.K.; Valantine, H.A.; Quake, S.R. Universal noninvasive detection of solid organ transplant rejection. Proc. Natl. Acad. Sci. USA 2011, 108, 6229-6234. [CrossRef]

106. Nizovtseva, E.V.; Clauvelin, N.; Todolli, S.; Polikanov, Y.S.; Kulaeva, O.I.; Wengrzynek, S.; Olson, W.K.; Studitsky, V.M. Nucleosome-free DNA regions differentially affect distant communication in chromatin. Nucleic Acids Res. 2017, 45, 3059-3067. [CrossRef]

107. Teif, V.B.; Vainshtein, Y.; Caudron-Herger, M.; Mallm, J.P.; Marth, C.; Höfer, T.; Rippe, K. Genome-wide nucleosome positioning during embryonic stem cell development. Nat. Struct. Mol. Biol. 2012, 19, 1185-1192. [CrossRef]

108. Valouev, A.; Johnson, S.M.; Boyd, S.D.; Smith, C.L.; Fire, A.Z.; Sidow, A. Determinants of nucleosome organization in primary human cells. Nature 2011, 474, 516-520. [CrossRef]

109. Basile, M.S.; Fagone, P.; Mangano, K.; Mammana, S.; Magro, G.; Salvatorelli, L.; Li Destri, G.; La Greca, G.; Nicoletti, F.; Puleo, S.; et al. KCNMA1 Expression is Downregulated in Colorectal Cancer via Epigenetic Mechanisms. Cancers 2019, 11, 245. [CrossRef]

110. Balas, M.M.; Johnson, A.M. Exploring the mechanisms behind long noncoding RNAs and cancer. Noncoding RNA Res. 2018, 3, 108-117. [CrossRef]

111. Chakravarthi, B.V.; Nepal, S.; Varambally, S. Genomic and Epigenomic Alterations in Cancer. Am. J. Pathol. 2016, 186, 1724-1735. [CrossRef]

112. Jang, H.S.; Shin, W.J.; Lee, J.E.; Do, J.T. CpG and Non-CpG Methylation in Epigenetic Gene Regulation and Brain Function. Genes 2017, 8, 148. [CrossRef]

113. Candido, S.; Lupo, G.; Pennisi, M.; Basile, M.S.; Anfuso, C.D.; Petralia, M.C.; Gattuso, G.; Vivarelli, S.; Spandidos, D.A.; Libra, M.; et al. The analysis of miRNA expression profiling datasets reveals inverse microRNA patterns in glioblastoma and Alzheimer's disease. Oncol. Rep. 2019, 42, 911-922. [CrossRef] 
114. Falzone, L.; Romano, G.L.; Salemi, R.; Bucolo, C.; Tomasello, B.; Lupo, G.; Anfuso, C.D.; Spandidos, D.A.; Libra, M.; Candido, S. Prognostic significance of deregulated microRNAs in uveal melanomas. Mol. Med. Rep. 2019, 19, 2599-2610. [CrossRef] [PubMed]

115. Liang, W.; Zhao, Y.; Huang, W.; Gao, Y.; Xu, W.; Tao, J.; Yang, M.; Li, L.; Ping, W.; Shen, H.; et al. Non-invasive diagnosis of early-stage lung cancer using high-throughput targeted DNA methylation sequencing of circulating tumor DNA (ctDNA). Theranostics 2019, 9, 2056-2070. [CrossRef] [PubMed]

116. Giannopoulou, L.; Zavridou, M.; Kasimir-Bauer, S.; Lianidou, E.S. Liquid biopsy in ovarian cancer: The potential of circulating miRNAs and exosomes. Transl. Res. 2019, 205, 77-91. [CrossRef]

117. Menschikowski, M.; Jandeck, C.; Friedemann, M.; Nacke, B.; Hantsche, S.; Tiebel, O.; Sukocheva, O.; Hagelgans, A. Identification of rare levels of methylated tumor DNA fragments using an optimized bias based pre-amplification-digital droplet PCR (OBBPA-ddPCR). Oncotarget 2018, 9, 36137-36150. [CrossRef]

118. Pardini, B.; Sabo, A.A.; Birolo, G.; Calin, G.A. Noncoding RNAs in Extracellular Fluids as Cancer Biomarkers: The New Frontier of Liquid Biopsies. Cancers 2019, 11, 1170. [CrossRef]

119. Faria, G.; Silva, E.; Da Fonseca, C.; Quirico-Santos, T. Circulating Cell-Free DNA as a Prognostic and Molecular Marker for Patients with Brain Tumors under Perillyl Alcohol-Based Therapy. Int. J. Mol. Sci. 2018, 19, 1610. [CrossRef]

120. Huang, Z.H.; Li, L.H.; Hua, D. Quantitative analysis of plasma circulating DNA at diagnosis and during follow-up of breast cancer patients. Cancer Lett. 2006, 243, 64-70. [CrossRef]

121. Feng, G.; Ye, X.; Fang, F.; Pu, C.; Huang, H.; Li, G. Quantification of plasma cell-free DNA1 in predicting therapeutic efficacy of sorafenib on metastatic clear cell renal cell carcinoma. Dis. Markers 2013, 34, 105-111. [CrossRef]

122. Wan, J.; Zhu, L.; Jiang, Z.; Cheng, K. Monitoring of plasma cell-free DNA in predicting postoperative recurrence of clear cell renal cell carcinoma. Urol. Int. 2013, 91, 273-278. [CrossRef]

123. Madic, J.; Kiialainen, A.; Bidard, F.C.; Birzele, F.; Ramey, G.; Leroy, Q.; Rio Frio, T.; Vaucher, I.; Raynal, V.; Bernard, V.; et al. Circulating tumor DNA and circulating tumor cells in metastatic triple negative breast cancer patients. Int. J. Cancer 2015, 136, 2158-2165. [CrossRef]

124. Heida, M.; Auer, M.; Ulz, P.; Heitzer, E.; Petru, E.; Gasch, C.; Riethdorf, S.; Mauermann, O.; Lafer, I.; Pristauz, G.; et al. The dynamic range of circulating tumor DNA in metastatic breast cancer. Breast Cancer Res. 2014, 16, 421. [CrossRef]

125. Birkenkamp-Demtröder, K.; Nordentoft, I.; Christensen, E.; Høyer, S.; Reinert, T.; Vang, S.; Borre, M.; Agerbæk, M.; Jensen, J.B.; Ørntoft, T.F.; et al. Genomic Alterations in Liquid Biopsies from Patients with Bladder Cancer. Eur. Urol. 2016, 70, 75-82. [CrossRef]

126. Salemi, R.; Falzone, L.; Madonna, G.; Polesel, J.; Cinà, D.; Mallardo, D.; Ascierto, P.A.; Libra, M.; Candido, S. MMP-9 as a Candidate Marker of Response to BRAF Inhibitors in Melanoma Patients With BRAFV600E Mutation Detected in Circulating-Free DNA. Front. Pharmacol. 2018, 9, 856. [CrossRef]

127. Kuang, Y.; O'Connell, A.; Sacher, A.G.; Feeney, N.; Alden, R.S.; Oxnard, G.R.; Paweletz, C.P. Monitoring of Response and Resistance in Plasma of EGFR-Mutant Lung Cancer Using Droplet Digital PCR. Methods Mol. Biol. 2018, 1768, 193-207.

128. Schøler, L.V.; Reinert, T.; Ørntoft, M.W.; Kassentoft, C.G.; Árnadóttir, S.S.; Vang, S.; Nordentoft, I.; Knudsen, M.; Lamy, P.; Andreasen, D.; et al. Clinical Implications of Monitoring Circulating Tumor DNA in Patients with Colorectal Cancer. Clin. Cancer Res. 2017, 23, 5437-5445. [CrossRef]

129. Sanmamed, M.F.; Fernández-Landázuri, S.; Rodríguez, C.; Zárate, R.; Lozano, M.D.; Zubiri, L.; Perez-Gracia, J.L.; Martín-Algarra, S.; González, A. Quantitative cell-free circulating BRAFV600E mutation analysis by use of droplet digital PCR in the follow-up of patients with melanoma being treated with BRAF inhibitors. Clin. Chem. 2015, 61, 297-304. [CrossRef]

130. Thompson, J.R.; Menon, S.P. Liquid Biopsies and Cancer Immunotherapy. Cancer J. 2018, 24,78-83. [CrossRef]

131. Khagi, Y.; Goodman, A.M.; Daniels, G.A.; Patel, S.P.; Sacco, A.G.; Randall, J.M.; Bazhenova, L.A.; Kurzrock, R. Hypermutated Circulating Tumor DNA: Correlation with Response to Checkpoint Inhibitor-Based Immunotherapy. Clin. Cancer Res. 2017, 23, 5729-5736. [CrossRef]

132. Chae, Y.K.; Davis, A.A.; Agte, S.; Pan, A.; Simon, N.I.; Iams, W.T.; Cruz, M.R.; Tamragouri, K.; Rhee, K.; Mohindra, N.; et al. Clinical Implications of Circulating Tumor DNA Tumor Mutational Burden (ctDNA TMB) in Non-Small Cell Lung Cancer. Oncologist 2019, 24, 820-828. [CrossRef] 
133. Xi, L.; Pham, T.H.; Payabyab, E.C.; Sherry, R.M.; Rosenberg, S.A.; Raffeld, M. Circulating Tumor DNA as an Early Indicator of Response to T-cell Transfer Immunotherapy in Metastatic Melanoma. Clin. Cancer Res. 2016, 22, 5480-5486. [CrossRef]

134. Tzanikou, E.; Markou, A.; Politaki, E.; Koutsopoulos, A.; Psyrri, A.; Mavroudis, D.; Georgoulias, V.; Lianidou, E. PIK3CA hotspot mutations in circulating tumor cells and paired circulating tumor DNA in breast cancer: A direct comparison study. Mol. Oncol. 2019. [CrossRef]

135. Delfau-Larue, M.H.; van der Gucht, A.; Dupuis, J.; Jais, J.P.; Nel, I.; Beldi-Ferchiou, A.; Hamdane, S.; Benmaad, I.; Laboure, G.; Verret, B.; et al. Total metabolic tumor volume, circulating tumor cells, cell-free DNA: Distinct prognostic value in follicular lymphoma. Blood Adv. 2018, 2, 807-816. [CrossRef]

136. Rossi, G.; Mu, Z.; Rademaker, A.W.; Austin, L.K.; Strickland, K.S.; Costa, R.L.B.; Nagy, R.J.; Zagonel, V.; Taxter, T.J.; Behdad, A.; et al. Cell-Free DNA and Circulating Tumor Cells: Comprehensive Liquid Biopsy Analysis in Advanced Breast Cancer. Clin. Cancer Res. 2018, 24, 560-568. [CrossRef]

137. Leung, F.; Kulasingam, V.; Diamandis, E.P.; Hoon, D.S.; Kinzler, K.; Pantel, K.; Alix-Panabières, C. Circulating Tumor DNA as a Cancer Biomarker: Fact or Fiction? Clin. Chem. 2016, 62, 1054-1060. [CrossRef]

138. Vogelstein, B.; Kinzler, K.W. Digital PCR. Proc. Natl. Acad. Sci. USA 1999, 96, 9236-9241. [CrossRef]

139. Olmedillas-López, S.; García-Arranz, M.; García-Olmo, D. Current and emerging applications of droplet digital PCR in oncology. Mol. Diagn. Ther. 2017, 21, 493-510. [CrossRef]

140. Hindson, C.M.; Chevillet, J.R.; Briggs, H.A.; Gallichotte, E.N.; Ruf, I.K.; Hindson, B.J.; Vessella, R.L.; Tewari, M. Absolute quantification by droplet digital PCR versus analog real-time PCR. Nat. Methods 2013, 10, 1003-1005. [CrossRef]

141. Crona, J.; Verdugo, A.D.; Granberg, D.; Welin, S.; Stålberg, P.; Hellman, P.; Björklund, P. Next-generation sequencing in the clinical genetic screening of patients with pheochromocytoma and paraganglioma. Endocr. Connect. 2013, 2, 104-111. [CrossRef]

142. Pinheiro, L.B.; Coleman, V.A.; Hindson, C.M.; Herrmann, J.; Hindson, B.J.; Bhat, S.; Emslie, K.R. Evaluation of a droplet digital polymerase chain reaction format for DNA copy number quantification. Anal. Chem. 2012, 84, 1003-1011. [CrossRef]

143. Hindson, B.J.; Ness, K.D.; Masquelier, D.A.; Belgrader, P.; Heredia, N.J.; Makarewicz, A.J.; Bright, I.J.; Lucero, M.Y.; Hiddessen, A.L.; Legler, T.C.; et al. High-throughput droplet digital PCR system for absolute quantitation of DNA copy number. Anal. Chem. 2011, 83, 8604-8610. [CrossRef]

144. Bell, A.D.; Usher, C.L.; McCarroll, S.A. Analyzing copy number variation with droplet digital PCR. In Digital PCR; Humana Press: New York, NY, USA, 2018; pp. 143-160.

145. Karlin-Neumann, G.; Bizouarn, F. Entering the Pantheon of 21 st Century Molecular Biology Tools: A Perspective on Digital PCR. In Digital PCR; Humana Press: New York, NY, USA, 2018; pp. 3-10.

146. McBride, D.J.; Orpana, A.K.; Sotiriou, C.; Joensuu, H.; Stephens, P.J.; Mudie, L.J.; Hämäläinen, E.; Stebbings, L.A.; Andersson, L.C.; Flanagan, A.M.; et al. Use of cancer-specific genomic rearrangements to quantify disease burden in plasma from patients with solid tumors. Genes Chromosomes Cancer 2010, 49, 1062-1069. [CrossRef]

147. Oellerich, M.; Schütz, E.; Beck, J.; Kanzow, P.; Plowman, P.N.; Weiss, G.J.; Walson, P.D. Using circulating cell-free DNA to monitor personalized cancer therapy. Crit. Rev. Clin. Lab. Sci. 2017, 54, 205-218. [CrossRef]

148. Christensen, E.; Birkenkamp-Demtröder, K.; Nordentoft, I.; Høyer, S.; van der Keur, K.; van Kessel, K.; Zwarthoff, E.; Agerbæk, M.; Ørntoft, T.F.; Jensen, J.B.; et al. Liquid Biopsy Analysis of FGFR3 and PIK3CA Hotspot Mutations for Disease Surveillance in Bladder Cancer. Eur. Urol. 2017, 71, 961-969. [CrossRef]

149. Tate, J.G.; Bamford, S.; Jubb, H.C.; Sondka, Z.; Beare, D.M.; Bindal, N.; Boutselakis, H.; Cole, C.G.; Creatore, C.; Dawson, E.; et al. COSMIC: The Catalogue Of Somatic Mutations In Cancer. Nucleic Acids Res. 2019, 47, D941-D947. [CrossRef]

150. Cancer Genome Atlas Research Network; Weinstein, J.N.; Collisson, E.A.; Mills, G.B.; Shaw, K.R.; Ozenberger, B.A.; Ellrott, K.; Shmulevich, I.; Sander, C.; Stuart, J.M. The Cancer Genome Atlas Pan-Cancer analysis project. Nat. Genet. 2013, 45, 1113-1120.

151. Barrett, T.; Wilhite, S.E.; Ledoux, P.; Evangelista, C.; Kim, I.F.; Tomashevsky, M.; Marshall, K.A.; Phillippy, K.H.; Sherman, P.M.; Holko, M.; et al. NCBI GEO: Archive for functional genomics data sets-update. Nucleic Acids Res. 2013, 41, D991-D995. [CrossRef] 
152. McCubrey, J.A.; Fitzgerald, T.L.; Yang, L.V.; Lertpiriyapong, K.; Steelman, L.S.; Abrams, S.L.; Montalto, G.; Cervello, M.; Neri, L.M.; Cocco, L.; et al. Roles of GSK-3 and microRNAs on epithelial mesenchymal transition and cancer stem cells. Oncotarget 2017, 8, 14221-14250. [CrossRef]

153. Falzone, L.; Scola, L.; Zanghì, A.; Biondi, A.; Di Cataldo, A.; Libra, M.; Candido, S. Integrated analysis of colorectal cancer microRNA datasets: Identification of microRNAs associated with tumor development. Aging 2018, 10, 1000-1014. [CrossRef]

154. Polo, A.; Crispo, A.; Cerino, P.; Falzone, L.; Candido, S.; Giudice, A.; De Petro, G.; Ciliberto, G.; Montella, M.; Budillon, A.; et al. Environment and bladder cancer: Molecular analysis by interaction networks. Oncotarget 2017, 8, 65240-65252. [CrossRef]

155. Falzone, L.; Candido, S.; Salemi, R.; Basile, M.S.; Scalisi, A.; McCubrey, J.A.; Torino, F.; Signorelli, S.S.; Montella, M.; Libra, M. Computational identification of microRNAs associated to both epithelial to mesenchymal transition and NGAL/MMP-9 pathways in bladder cancer. Oncotarget 2016, 8, 72758-72766. [CrossRef]

156. Hafsi, S.; Candido, S.; Maestro, R.; Falzone, L.; Soua, Z.; Bonavida, B.; Spandidos, D.A.; Libra, M. Correlation between the overexpression of Yin Yang 1 and the expression levels of miRNAs in Burkitt's lymphoma: A computational study. Oncol. Lett. 2016, 11, 1021-1025. [CrossRef]

157. Presti, M.; Mazzon, E.; Basile, M.S.; Petralia, M.C.; Bramanti, A.; Colletti, G.; Bramanti, P.; Nicoletti, F.; Fagone, P. Overexpression of macrophage migration inhibitory factor and functionally-related genes, D-DT, CD74, CD44, CXCR2 and CXCR4, in glioblastoma. Oncol. Lett. 2018, 16, 2881-2886. [CrossRef]

158. Petralia, M.C.; Mazzon, E.; Fagone, P.; Russo, A.; Longo, A.; Avitabile, T.; Nicoletti, F.; Reibaldi, M.; Basile, M.S. Characterization of the Pathophysiological Role of CD47 in Uveal Melanoma. Molecules 2019, $24,2450$. [CrossRef]

159. Leonardi, G.C.; Falzone, L.; Salemi, R.; Zanghì, A.; Spandidos, D.A.; Mccubrey, J.A.; Candido, S.; Libra, M. Cutaneous melanoma: From pathogenesis to therapy (Review). Int. J. Oncol. 2018, 52, 1071-1080. [CrossRef]

160. Guarneri, C.; Bevelacqua, V.; Polesel, J.; Falzone, L.; Cannavò, P.S.; Spandidos, D.A.; Malaponte, G.; Libra, M. $\mathrm{NF} \kappa \mathrm{B}$ inhibition is associated with OPN/MMP 9 downregulation in cutaneous melanoma. Oncol. Rep. 2017, 37, 737-746. [CrossRef]

161. Fan, G.; Zhang, K.; Ding, J.; Li, J. Prognostic value of EGFR and KRAS in circulating tumor DNA in patients with advanced non-small cell lung cancer: A systematic review and meta-analysis. Oncotarget 2017, 8 , 33922-33932. [CrossRef]

162. Nikolouzakis, T.K.; Stivaktakis, P.D.; Apalaki, P.; Kalliantasi, K.; Sapsakos, T.M.; Spandidos, D.A.; Tsatsakis, A.; Souglakos, J.; Tsiaoussis, J. Effect of systemic treatment on the micronuclei frequency in the peripheral blood of patients with metastatic colorectal cancer. Oncol. Lett. 2019, 17, 2703-2712. [CrossRef]

163. Neagu, M.; Constantin, C.; Popescu, I.D.; Zipeto, D.; Tzanakakis, G.; Nikitovic, D.; Fenga, C.; Stratakis, C.A.; Spandidos, D.A.; Tsatsakis, A.M. Inflammation and Metabolism in Cancer Cell-Mitochondria Key Player. Front. Oncol. 2019, 9, 348. [CrossRef]

164. Nikolouzakis, T.K.; Vassilopoulou, L.; Fragkiadaki, P.; Mariolis Sapsakos, T.; Papadakis, G.Z.; Spandidos, D.A.; Tsatsakis, A.M.; Tsiaoussis, J. Improving diagnosis, prognosis and prediction by using biomarkers in CRC patients (Review). Oncol. Rep. 2018, 39, 2455-2472. [CrossRef]

165. Tänzer, M.; Balluff, B.; Distler, J.; Hale, K.; Leodolter, A.; Röcken, C.; Molnar, B.; Schmid, R.; Lofton-Day, C.; Schuster, T.; et al. Performance of epigenetic markers SEPT9 and ALX4 in plasma for detection of colorectal precancerous lesions. PLoS ONE 2010, 5, e9061. [CrossRef]

166. Danese, E.; Montagnana, M. Epigenetics of colorectal cancer: Emerging circulating diagnostic and prognostic biomarkers. Ann. Transl. Med. 2017, 5, 279. [CrossRef]

167. Garrigou, S.; Perkins, G.; Garlan, F.; Normand, C.; Didelot, A.; Le Corre, D.; Peyvandi, S.; Mulot, C.; Niarra, R.; Aucouturier, P.; et al. A Study of Hypermethylated Circulating Tumor DNA as a Universal Colorectal Cancer Biomarker. Clin. Chem. 2016, 62, 1129-1139. [CrossRef]

168. Jia, S.; Zhang, R.; Li, Z.; Li, J. Clinical and biological significance of circulating tumor cells, circulating tumor DNA, and exosomes as biomarkers in colorectal cancer. Oncotarget 2017, 8, 55632-55645. [CrossRef]

169. Negrei, C.; Hudita, A.; Ginghina, O.; Galateanu, B.; Voicu, S.N.; Stan, M.; Costache, M.; Fenga, C.; Drakoulis, N.; Tsatsakis, A.M. Colon Cancer Cells Gene Expression Signature As Response to 5- Fluorouracil, Oxaliplatin, and Folinic Acid Treatment. Front. Pharmacol. 2016, 7, 172. [CrossRef] 
170. Takayama, Y.; Suzuki, K.; Muto, Y.; Ichida, K.; Fukui, T.; Kakizawa, N.; Ishikawa, H.; Watanabe, F.; Hasegawa, F.; Saito, M.; et al. Monitoring circulating tumor DNA revealed dynamic changes in KRAS status in patients with metastatic colorectal cancer. Oncotarget 2018, 9, 24398-24413. [CrossRef]

171. Mouliere, F.; El Messaoudi, S.; Gongora, C.; Guedj, A.S.; Robert, B.; Del Rio, M.; Molina, F.; Lamy, P.J.; Lopez-Crapez, E.; Mathonnet, M.; et al. Circulating Cell-Free DNA from Colorectal Cancer Patients May Reveal High KRAS or BRAF Mutation Load. Transl. Oncol. 2013, 6, 319-328. [CrossRef]

172. Ghatalia, P.; Smith, C.H.; Winer, A.; Gou, J.; Kiedrowski, L.A.; Slifker, M.; Saltzberg, P.D.; Bubes, N.; Anari, F.M.; Kasireddy, V.; et al. Clinical Utilization Pattern of Liquid Biopsies (LB) to Detect Actionable Driver Mutations, Guide Treatment Decisions and Monitor Disease Burden During Treatment of 33 Metastatic Colorectal Cancer (mCRC) Patients (pts) at a Fox Chase Cancer Center GI Oncology Subspecialty Clinic. Front. Oncol. 2019, 8, 652.

173. Gabriel, E.; Bagaria, S.P. Assessing the Impact of Circulating Tumor DNA (ctDNA) in Patients with Colorectal Cancer: Separating Fact From Fiction. Front. Oncol. 2018, 8, 297. [CrossRef]

174. Shang, M.; Chang, C.; Pei, Y.; Guan, Y.; Chang, J.; Li, H. Potential Management of Circulating Tumor DNA as a Biomarker in Triple-Negative Breast Cancer. J. Cancer 2018, 9, 4627-4634. [CrossRef]

175. Ishiba, T.; Hoffmann, A.C.; Usher, J.; Elshimali, Y.; Sturdevant, T.; Dang, M.; Jaimes, Y.; Tyagi, R.; Gonzales, R.; Grino, M.; et al. Frequencies and expression levels of programmed death ligand 1 (PD-L1) in circulating tumor RNA (ctRNA) in various cancer types. Biochem. Biophys. Res. Commun. 2018, 500, 621-625. [CrossRef]

176. Kodahl, A.R.; Ehmsen, S.; Pallisgaard, N.; Jylling, A.M.B.; Jensen, J.D.; Laenkholm, A.V.; Knoop, A.S.; Ditzel, H.J. Correlation between circulating cell-free PIK3CA tumor DNA levels and treatment response in patients with PIK3CA-mutated metastatic breast cancer. Mol. Oncol. 2018, 12, 925-935. [CrossRef] [PubMed]

177. Sacher, A.G.; Paweletz, C.; Dahlberg, S.E.; Alden, R.S.; O'Connell, A.; Feeney, N.; Mach, S.L.; Jänne, P.A.; Oxnard, G.R. Prospective Validation of Rapid Plasma Genotyping for the Detection of EGFR and KRAS Mutations in Advanced Lung Cancer. JAMA Oncol. 2016, 2, 1014-1022. [CrossRef] [PubMed]

178. Tsui, D.W.Y.; Murtaza, M.; Wong, A.S.C.; Rueda, O.M.; Smith, C.G.; Chandrananda, D.; Soo, R.A.; Lim, H.L.; Goh, B.C.; Caldas, C.; et al. Dinamics of multiple resistance mechanisms in plasma DNA during EGFR-targeted therapies in non-small cell lung cancer. EMBO Mol. Med. 2018, 10, e7945. [CrossRef] [PubMed]

179. Marchetti, A.; Del Grammastro, M.; Felicioni, L.; Malatesta, S.; Filice, G.; Centi, I.; De Pas, T.; Santoro, A.; Chella, A.; Brandes, A.A.; et al. Assessment of EGFR mutations in circulating tumor cell preparations from NSCLC patients by next generation sequencing: Toward a real-time liquid biopsy for treatment. PLoS ONE 2014, 9, e103883. [CrossRef] [PubMed]

180. Boffa, D.J.; Graf, R.P.; Salazar, M.C.; Hoag, J.; Lu, D.; Krupa, R.; Louw, J.; Dugan, L.; Wang, Y.; Landers, M.; et al. Cellular Expression of PD-L1 in the Peripheral Blood of Lung Cancer Patients is Associated with Worse Survival. Cancer Epidemiol. Biomarkers Prev. 2017, 26, 1139-1145. [CrossRef]

181. Nicolazzo, C.; Raimondi, C.; Mancini, M.; Caponnetto, S.; Gradilone, A.; Gandini, O.; Mastromartino, M.; Del Bene, G.; Prete, A.; Longo, F.; et al. Monitoring PD-L1 positive circulating tumor cells in non-small cell lung cancer patients treated with the PD-1 inhibitor Nivolumab. Sci. Rep. 2016, 6, 31726. [CrossRef]

182. Heitzer, E.; Auer, M.; Gasch, C.; Pichler, M.; Ulz, P.; Hoffmann, E.M.; Lax, S.; Waldispuehl-Geigl, J.; Mauermann, O.; Lackner, C.; et al. Complex tumor genomes inferred from single circulating tumor cells by array-CGH and next-generation sequencing. Cancer Res. 2013, 73, 2965-2975. [CrossRef]

183. Myint, N.N.M.; Verma, A.M.; Fernandez-Garcia, D.; Sarmah, P.; Tarpey, P.S.; Al-Aqbi, S.S.; Cai, H.; Trigg, R.; West, K.; Howells, L.M.; et al. Circulating tumor DNA in patients with colorectal adenomas: Assessment of detectability and genetic heterogeneity. Cell Death Dis. 2018, 9, 894. [CrossRef]

184. Galbiati, S.; Damin, F.; Burgio, V.; Brisci, A.; Soriani, N.; Belcastro, B.; Di Resta, C.; Gianni, L.; Chiari, M.; Ronzoni, M.; et al. Evaluation of three advanced methodologies, COLD-PCR, microarray and ddPCR, for identifying the mutational status by liquid biopsies in metastatic colorectal cancer patients. Clin. Chim. Acta 2019, 489, 136-143. [CrossRef]

185. Osumi, H.; Shinozaki, E.; Takeda, Y.; Wakatsuki, T.; Ichimura, T.; Saiura, A.; Yamaguchi, K.; Takahashi, S.; Noda, T.; Zembutsu, H. Clinical relevance of circulating tumor DNA assessed through deep sequencing in patients with metastatic colorectal cancer. Cancer Med. 2019, 8, 408-417. [CrossRef]

186. Kondo, Y.; Hayashi, K.; Kawakami, K.; Miwa, Y.; Hayashi, H.; Yamamoto, M. KRAS mutation analysis of single circulating tumor cells from patients with metastatic colorectal cancer. BMC Cancer 2017, 17, 311. [CrossRef] [PubMed] 
187. Damin, F.; Galbiati, S.; Soriani, N.; Burgio, V.; Ronzoni, M.; Ferrari, M.; Chiari, M. Analysis of KRAS, NRAS and BRAF mutational profile by combination of in-tube hybridization and universal tag-microarray in tumor tissue and plasma of colorectal cancer patients. PLOS ONE 2018, 13, e0207876. [CrossRef] [PubMed]

188. Garlan, F.; Laurent-Puig, P.; Sefrioui, D.; Siauve, N.; Didelot, A.; Sarafan-Vasseur, N.; Michel, P.; Perkins, G.; Mulot, C.; Blons, H.; et al. Early Evaluation of Circulating Tumor DNA as Marker of Therapeutic Efficacy in Metastatic Colorectal Cancer Patients (PLACOL Study). Clin. Cancer Res. 2017, 23, 5416-5425. [CrossRef] [PubMed]

189. Kidess-Sigal, E.; Liu, H.E.; Triboulet, M.M.; Che, J.; Ramani, V.C.; Visser, B.C.; Poultsides, G.A.; Longacre, T.A.; Marziali, A.; Vysotskaia, V.; et al. Enumeration and targeted analysis of KRAS, BRAF and PIK3CA mutations in CTCs captured by a label-free platform: Comparison to ctDNA and tissue in metastatic colorectal cancer. Oncotarget 2016, 7, 85349-85364. [CrossRef]

190. Grützmann, R.; Molnar, B.; Pilarsky, C.; Habermann, J.K.; Schlag, P.M.; Saeger, H.D.; Miehlke, S.; Stolz, T.; Model, F.; Roblick, U.J.; et al. Sensitive detection of colorectal cancer in peripheral blood by septin 9 DNA methylation assay. PLoS ONE 2008, 3, e3759. [CrossRef] [PubMed]

191. Lee, J.; Franovic, A.; Shiotsu, Y.; Kim, S.T.; Kim, K.M.; Banks, K.C.; Raymond, V.M.; Lanman, R.B. Detection of ERBB2 (HER2) Gene Amplification Events in Cell-Free DNA and Response to Anti-HER2 Agents in a Large Asian Cancer Patient Cohort. Front. Oncol. 2019, 9, 212. [CrossRef] [PubMed]

192. Chen, W.; Zhang, J.; Huang, L.; Chen, L.; Zhou, Y.; Tang, D.; Xie, Y.; Wang, H.; Huang, C. Detection of HER2-positive Circulating Tumor Cells Using the LiquidBiopsy System in Breast Cancer. Clin. Breast Cancer 2019, 19, e239-e246. [CrossRef]

193. Mazel, M.; Jacot, W.; Pantel, K.; Bartkowiak, K.; Topart, D.; Cayrefourcq, L.; Rossille, D.; Maudelonde, T.; Fest, T.; Alix-Panabières, C. Frequent expression of PD-L1 on circulating breast cancer cells. Mol. Oncol. 2015, 9, 1773-1782. [CrossRef]

194. Savli, H.; Sertdemir, N.; Aydin, D.; Dursun, B.; Kurtas, O.; Reka, S.; Sunnetci-Akkoyunlu, D.; Eren-Keskin, S.; Uygun, K.; Ozden, E.; et al. TP53, EGFR and PIK3CA gene variations observed as prominent biomarkers in breast and lung cancer by plasma cell-free DNA genomic testing. J. Biotechnol. 2019, 300, 87-93. [CrossRef]

195. Nakauchi, C.; Kagara, N.; Shimazu, K.; Shimomura, A.; Naoi, Y.; Shimoda, M.; Kim, S.J.; Noguchi, S. Detection of TP53/PIK3CA Mutations in Cell-Free Plasma DNA From Metastatic Breast Cancer Patients Using Next Generation Sequencing. Clin. Breast Cancer 2016, 16, 418-423. [CrossRef]

196. Reid, A.L.; Freeman, J.B.; Millward, M.; Ziman, M.; Gray, E.S. Detection of BRAF-V600E and V600K in melanoma circulating tumour cells by droplet digital PCR. Clin. Biochem. 2015, 48, 999-1002. [CrossRef] [PubMed]

197. Ahlborn, L.B.; Tuxen, I.V.; Mouliere, F.; Kinalis, S.; Schmidt, A.Y.; Rohrberg, K.S.; Santoni-Rugiu, E.; Nielsen, F.C.; Lassen, U.; Yde, C.W.; et al. Circulating tumor DNA as a marker of treatment response in BRAF V600E mutated non-melanoma solid tumors. Oncotarget 2018, 9, 32570-32579. [CrossRef] [PubMed]

198. Stadler, J.; Eder, J.; Pratscher, B.; Brandt, S.; Schneller, D.; Müllegger, R.; Vogl, C.; Trautinger, F.; Brem, G.; Burgstaller, J.P. SNPase-ARMS qPCR: Ultrasensitive Mutation-Based Detection of Cell-Free Tumor DNA in Melanoma Patients. PLoS ONE 2015, 10, e0142273. [CrossRef] [PubMed]

199. Tan, L.; Sandhu, S.; Lee, R.J.; Li, J.; Callahan, J.; Ftouni, S.; Dhomen, N.; Middlehurst, P.; Wallace, A.; Raleigh, J.; et al. Prediction and monitoring of relapse in stage III melanoma using circulating tumor DNA. Ann. Oncol. 2019, 30, 804-814. [CrossRef] [PubMed]

200. Luo, X.; Mitra, D.; Sullivan, R.J.; Wittner, B.S.; Kimura, A.M.; Pan, S.; Hoang, M.P.; Brannigan, B.W.; Lawrence, D.P.; Flaherty, K.T.; et al. Isolation and molecular characterization of circulating melanoma cells. Cell Rep. 2014, 7, 645-653. [CrossRef] [PubMed]

201. Gangadhar, T.C.; Savitch, S.L.; Yee, S.S.; Xu, W.; Huang, A.C.; Harmon, S.; Lieberman, D.B.; Soucier, D.; Fan, R.; Black, T.A.; et al. Feasibility of monitoring advanced melanoma patients using cell-free DNA from plasma. Pigment Cell Melanoma Res. 2018, 31, 73-81. [CrossRef]

202. Bonaparte, E.; Pesenti, C.; Fontana, L.; Falcone, R.; Paganini, L.; Marzorati, A.; Ferrero, S.; Nosotti, M.; Mendogni, P.; Bareggi, C.; et al. Molecular profiling of lung cancer specimens and liquid biopsies using MALDI-TOF mass spectrometry. Diagn. Pathol. 2018, 13, 4. [CrossRef]

203. Sakaizawa, K.; Goto, Y.; Kiniwa, Y.; Uchiyama, A.; Harada, K.; Shimada, S.; Saida, T.; Ferrone, S.; Takata, M.; Uhara, H.; et al. Mutation analysis of BRAF and KIT in circulating melanoma cells at the single cell level. $\mathrm{Br}$. J. Cancer 2012, 106, 939-946. [CrossRef] 
204. Silantyev, A.S.; Falzone, L.; Libra, M.; Gurina, O.I.; Kardashova, K.S.; Nikolouzakis, T.K.; Nosyrev, A.E.; Sutton, C.W.; Mitsias, P.D.; Tsatsakis, A. Current and Future Trends on Diagnosis and Prognosis of Glioblastoma: From Molecular Biology to Proteomics. Cells 2019, 8. [CrossRef]

205. Basile, M.S.; Mazzon, E.; Krajnovic, T.; Draca, D.; Cavalli, E.; Al-Abed, Y.; Bramanti, P.; Nicoletti, F.; Mijatovic, S.; Maksimovic-Ivanic, D. Anticancer and Differentiation Properties of the Nitric Oxide Derivative of Lopinavir in Human Glioblastoma Cells. Molecules 2018, 23, 2463. [CrossRef]

206. Chen, J.; Huan, W.; Zuo, H.; Zhao, L.; Huang, C.; Liu, X.; Hou, S.; Qi, J.; Shi, W. Alu methylation serves as a biomarker for non-invasive diagnosis of glioma. Oncotarget 2016, 7, 26099-26106. [CrossRef] [PubMed]

207. Toraño, E.G.; Petrus, S.; Fernandez, A.F.; Fraga, M.F. Global DNA hypomethylation in cancer: Review of validated methods and clinical significance. Clin. Chem. Lab. Med. 2012, 50, 1733-1742. [CrossRef] [PubMed]

208. Piccioni, D.E.; Achrol, A.S.; Kiedrowski, L.A.; Banks, K.C.; Boucher, N.; Barkhoudarian, G.; Kelly, D.F.; Juarez, T.; Lanman, R.B.; Raymond, V.M.; et al. Analysis of cell-free circulating tumor DNA in 419 patients with glioblastoma and other primary brain tumors. CNS Oncol. 2019, 8, CNS34. [CrossRef] [PubMed]

209. Goessl, C.; Müller, M.; Straub, B.; Miller, K. DNA alterations in body fluids as molecular tumor markers for urological malignancies. Eur. Urol. 2002, 41, 668-676. [CrossRef]

210. Bergerot, P.G.; Hahn, A.W.; Bergerot, C.D.; Jones, J.; Pal, S.K. The Role of Circulating Tumor DNA in Renal Cell Carcinoma. Curr. Treat. Options Oncol. 2018, 19, 10. [CrossRef]

211. Ulz, P.; Belic, J.; Graf, R.; Auer, M.; Lafer, I.; Fischereder, K.; Webersinke, G.; Pummer, K.; Augustin, H.; Pichler, M.; et al. Whole-genome plasma sequencing reveals focal amplifications as a driving force in metastatic prostate cancer. Nat. Commun. 2016, 7, 12008. [CrossRef]

212. Scher, H.I.; Lu, D.; Schreiber, N.A.; Louw, J.; Graf, R.P.; Vargas, H.A.; Johnson, A.; Jendrisak, A.; Bambury, R.; Danila, D.; et al. Association of AR-V7 on Circulating Tumor Cells as a Treatment-Specific Biomarker With Outcomes and Survival in Castration-Resistant Prostate Cancer. JAMA Oncol. 2016, 2, 1441-1449. [CrossRef]

213. Azad, A.A.; Volik, S.V.; Wyatt, A.W.; Haegert, A.; Le Bihan, S.; Bell, R.H.; Anderson, S.A.; McConeghy, B.; Shukin, R.; Bazov, J.; et al. Androgen Receptor Gene Aberrations in Circulating Cell-Free DNA: Biomarkers of Therapeutic Resistance in Castration-Resistant Prostate Cancer. Clin. Cancer Res. 2015, 21, 2315-2324. [CrossRef]

214. Romanel, A.; Gasi Tandefelt, D.; Conteduca, V.; Jayaram, A.; Casiraghi, N.; Wetterskog, D.; Salvi, S.; Amadori, D.; Zafeiriou, Z.; Rescigno, P.; et al. Plasma AR and abiraterone-resistant prostate cancer. Sci. Transl. Med. 2015, 7, 312re10. [CrossRef]

215. Antonarakis, E.S.; Lu, C.; Wang, H.; Luber, B.; Nakazawa, M.; Roeser, J.C.; Chen, Y.; Mohammad, T.A.; Chen, Y.; Fedor, H.L.; et al. AR-V7 and resistance to enzalutamide and abiraterone in prostate cancer. $N$. Engl. J. Med. 2014, 371, 1028-1038. [CrossRef]

216. Parimi, S.; Ko, J.J. Recent advances in circulating tumor cells and cell-free DNA in metastatic prostate cancer: A review. Expert Rev. Anticancer 2017, 17, 939-949. [CrossRef] [PubMed]

217. Brisuda, A.; Pazourkova, E.; Soukup, V.; Horinek, A.; Hrbáček, J.; Capoun, O.; Svobodova, I.; Pospisilova, S.; Korabecna, M.; Mares, J.; et al. Urinary Cell-Free DNA Quantification as Non-Invasive Biomarker in Patients with Bladder Cancer. Urol. Int. 2016, 96, 25-31. [CrossRef] [PubMed]

218. Casadio, V.; Calistri, D.; Tebaldi, M.; Bravaccini, S.; Gunelli, R.; Martorana, G.; Bertaccini, A.; Serra, L.; Scarpi, E.; Amadori, D.; et al. Urine cell-free DNA integrity as a marker for early bladder cancer diagnosis: Preliminary data. Urol. Oncol. 2013, 31, 1744-1750. [CrossRef] [PubMed]

219. Fantony, J.J.; Longo, T.A.; Gopalakrishna, A.; Owusu, R.; Lance, R.S.; Foo, W.C.; Inman, B.A.; Abern, M.R. Urinary NID2 and TWIST1 methylation to augment conventional urine cytology for the detection of bladder cancer. Cancer Biomark. 2017, 18, 381-387. [CrossRef]

220. Yegin, Z.; Gunes, S.; Buyukalpelli, R. Hypermethylation of TWIST1 and NID2 in tumor tissues and voided urine in urinary bladder cancer patients. DNA Cell Biol. 2013, 32, 386-392. [CrossRef]

221. Renard, I.; Joniau, S.; van Cleynenbreugel, B.; Collette, C.; Naômé, C.; Vlassenbroeck, I.; Nicolas, H.; de Leval, J.; Straub, J.; Van Criekinge, W.; et al. Identification and validation of the methylated TWIST1 and NID2 genes through real-time methylation-specific polymerase chain reaction assays for the noninvasive detection of primary bladder cancer in urine samples. Eur. Urol. 2010, 58, 96-104. [CrossRef]

222. Springer, S.U.; Chen, C.H.; Rodriguez Pena, M.D.C.; Li, L.; Douville, C.; Wang, Y.; Cohen, J.D.; Taheri, D.; Silliman, N.; Schaefer, J.; et al. Non-invasive detection of urothelial cancer through the analysis of driver gene mutations and aneuploidy. Elife 2018, 7, e32143. [CrossRef] 
223. Eich, M.L.; Rodriguez Pena, M.D.C.; Springer, S.U.; Taheri, D.; Tregnago, A.C.; Salles, D.C.; Bezerra, S.M.; Cunha, I.W.; Fujita, K.; Ertoy, D.; et al. Incidence and distribution of UroSEEK gene panel in a multi-institutional cohort of bladder urothelial carcinoma. Mod. Pathol. 2019, 32, 1544-1550. [CrossRef]

224. Haff, L.A.; Belden, A.C.; Hall, L.R.; Ross, P.L.; Smirnov, I.P. SNP Genotyping by MALDI-TOF Mass Spectrometry. In Mass Spectrometry and Genomic Analysis. Housby, J.N., Ed.; Kluwer Academic Publisher: Dordrecht, The Netherlands, 2001; pp. 16-32.

225. Sharma, V.K.; Vouros, P.; Glick, J. Mass spectrometric based analysis, characterization and applications of circulating cell free DNA isolated from human body fluids. Int. J. Mass Spectrom. 2011, 304, 172-183. [CrossRef]

226. Vogelstein, B.; Papadopoulos, N.; Velculescu, V.E.; Zhou, S.; Diaz, L.A.; Kinzler, K.W. Cancer genome landscapes. Science 2013, 339, 1546-1558. [CrossRef]

227. Grzywa, T.M.; Paskal, W.; Włodarski, P.K. Intratumor and Intertumor Heterogeneity in Melanoma. Transl. Oncol. 2017, 10, 956-975. [CrossRef] [PubMed]

228. Rink, M.; Shariat, S.F.; Soave, A. Liquid biopsies in bladder cancer-did we find the Holy Grail for biomarker analyses? Transl. Androl. Urol. 2016, 5, 980-983. [CrossRef] [PubMed]

229. Cirrone, G.A.P.; Margarone, D.; Maggiore, M.; Anzalone, A.; Borghesi, M.; Jia, S.B.; Bulanov, S.S.; Bulanov, S.; Carpinelli, M.; Cavallaro, S.; et al. ELIMED: A new hadron therapy concept based on laser driven ion beams. Proc. SPIE 2013, 8779, 87791.

230. Van Soest, R.J. Liquid biopsies and plasma DNA: Paving the way for personalized medicine in metastatic castration-resistant prostate cancer. Ann. Oncol. 2017, 28, 1408-1409. [CrossRef] [PubMed]

231. Syn, N.L.; Teng, M.W.; Mok, T.S.; Soo, R.A. De-novo and acquired resistance to immune checkpoint targeting. Lancet Oncol. 2017, 18, e731-e741. [CrossRef]

232. Zhao, H.; Chen, K.Z.; Hui, B.G.; Zhang, K.; Yang, F.; Wang, J. Role of circulating tumor DNA in the management of early-stage lung cancer. Thorac. Cancer 2018, 9, 509-515. [CrossRef]

233. Babayan, A.; Pantel, K. Advances in liquid biopsy approaches for early detection and monitoring of cancer. Genome Med. 2018, 10, 21. [CrossRef]

234. Liang, W.; Zhao, Y.; Huang, W.; Liang, H.; Zeng, H.; He, J. Liquid biopsy for early stage lung cancer. J. Thorac. Dis. 2018, 10, S876-S881. [CrossRef]

235. Krug, A.K.; Enderle, D.; Karlovich, C.; Priewasser, T.; Bentink, S.; Spiel, A.; Brinkmann, K.; Emenegger, J.; Grimm, D.G.; Castellanos-Rizaldos, E.; et al. Improved EGFR mutation detection using combined exosomal RNA and circulating tumor DNA in NSCLC patient plasma. Ann. Oncol. 2018, 29, 2143. [CrossRef]

236. Mone, A. Johns Hopkins researchers develop single blood test that screens for eight common cancers. Available online: https://hub.jhu.edu/2018/01/19/cancer-blood-test-johns-hopkins/ (accessed on 13 October 2019).

(C) 2019 by the authors. Licensee MDPI, Basel, Switzerland. This article is an open access article distributed under the terms and conditions of the Creative Commons Attribution (CC BY) license (http://creativecommons.org/licenses/by/4.0/). 